Florida A\&M University College of Law Scholarly Commons @ FAMU Law

Journal Publications

Faculty Works

2006

\title{
Pro-Democratic Intervention in Africa
}

Jeremy I. Levitt

jeremy.levitt@famu.edu

Follow this and additional works at: http://commons.law.famu.edu/faculty-research

Part of the International Humanitarian Law Commons, International Law Commons, and the Military, War, and Peace Commons

\section{Recommended Citation}

Jeremy I. Levitt, Pro-Democratic Intervention in Africa, 24 Wis. Int'1 L.J. 785 (2006)

This Article is brought to you for free and open access by the Faculty Works at Scholarly Commons @ FAMU Law. It has been accepted for inclusion in Journal Publications by an authorized administrator of Scholarly Commons @ FAMU Law. For more information, please contact linda.barrette@famu.edu. 


\title{
PRO-DEMOCRATIC INTERVENTION IN AFRICA
}

\author{
JEREMY I. LEVITT
}

\section{INTRODUCTION}

In the past twenty years the people of the African continent have experienced human suffering on a scale unparalleled in human history. Millions of Africans, especially women and children, have been killed by deadly conflict in Angola $(650,000)$, the Democratic Republic of Congo (3 million), Sudan ( 2.5 million), Rwanda (1 million), Burundi $(300,000)$, Liberia $(250,000)$, Sierra Leone $(75,000)$, and Uganda $(40,000) .{ }^{1}$ Besides these huge fatalities, warfare has also affected democratization and human, social, and economic development; has led to the breakdown of the rule of law; and has allowed the catastrophic impact of the HIV/AIDS pandemic to reap havoc on Africa's human architecture. ${ }^{2}$

The international system of peace and security, including the scheme provided under the United Nations Charter framework,

"Dr. Jeremy Levitt is an associate professor of law at Florida International University College of Law and a distinguished research scholar at the Northern Illinois University College of Law. This article is dedicated to the loving memory of my dear friend, mentor and brother, Advocate James Thomas, former Associate Dean of Admissions and Financial Aid at the University of Wisconsin-Madison Law School. Sections of this article were taken with permission of the American Society of International Law, Global Dialogue, Ashgate Publishing, and the Temple Journal of International and Comparative Law from the following works of the author: Jeremy Levitt, The Evolving Intervention Regime in Africa: From Basket Case to Market Place?, 2002 AM. SOC'Y INT'L L. PROC. NINETY-SiXTH ANN. MEETING 136; Jeremy Levitt, The Law on Intervention: Africa's Pathbreaking Model, Global Dialogue, Winter/Spring 2005, at 50; Jeremy Levitt, African Interventionist States and International Law, in AFRICAN INTERVENTIONIST STATES 15 (Oliver Furley \& Roy May eds., 2001); Jeremy Levitt, Humanitarian Intervention by Regional Actors in Internal Conflicts: The Cases of ECOWAS in Liberia and Sierra Leone, 12 TEMP. INT'L \& COMP. L.J. 333 (1998); Jeremy I. Levitt, Illegal Peace?: Examining the Legality of Power-Sharing with Warlords and Rebels in Africa, $27 \mathrm{MICH}$. J. INT'L L. 495 (2006). The author would like to thank all of the participants at the symposium "Humanitarian Intervention After 9/11," held at the University of Wisconsin-Madison Law School on March 31, 2006, for their constructive comments on his presentation on prodemocratic intervention in Africa. He also thanks his graduate assistant, Jordan Dollar, for assisting in researching and drafting the background sections on São Tomé and Príncipe and Togo.

1 See generally Jeremy Levitt, The Law on Intervention: Africa's Pathbreaking Model, GLOBAL DIALOGUE, Winter/Spring 2005, at 50 [hereinafter Levitt, The Law on Intervention].

2 Id. 
has not offered a viable strategy to reduce armed conflict and human suffering and solidify democracy in Africa. For its part, the UN Security Council (UNSC) has been uninterested in or too slow to react to illegal seizures of power and armed conflict in the continent. ${ }^{3}$ It has also failed to forward an effective approach to assist states emerging from conflict to build, or rebuild, and sustain democracy-with the result too often being democratic elections without authentic democratic transitions. Consequently, African states and their organizations have sought to fashion African solutions to African problems by creating innovative rules and mechanisms for pro-democracy and human rightsbased intervention. These rules and structures are, in turn, evolving the law of intervention and, in my view, have been the most credible examples and the single most important force in the development of pro-democratic intervention (PDI) and humanitarian intervention norms.

For the past decade I have examined and documented the evolution of Africa's peacekeeping, peace enforcement, regional collective security, and conflict management landscape as well as Africa's contribution to international law, particularly as it relates to the jus ad bellum, "the law of the use of force". Although an abundance of scholarly work and official studies have examined the complexities of humanitarian intervention, ${ }^{4}$ only a select body of credible work has considered the phenomenon of PDI-very little of which has made mention of Africa. Given that Africa has developed the most radical and unique approach to PDI in the world, the lack of study is unfortunate.

This Article offers a conceptual framework to locate PDI in international law. It is limited to the identification of PDI as an emerging norm of international law deeply rooted in the African experience. As Fernando Tesón notes, PDI is anchored in the belief that "the principle of democratic rule is today part of international law"5 and that state practice has "evaluated the principle of democracy to the category of a rule which is fully enforceable through appropriate regional

3 Id.

4 See, e.g., Int'l Comm'n on Intervention and State Sovereignty [ICISS], The Responsibility to Protect (Dec. 2001), available at http://www.iciss.ca/pdf/Commission-Report.pdf; see also ICISS, The Responsibility to Protect: Research, Bibliography, Background (Dec. 2001) (prepared by Thomas G. Weiss \& Don Hubert), available at http://www.iciss.ca/pdf/ Supplementary-Volume.pdf [hereinafter ICISS, The Responsibility to Protect: Bibliography].

5 Fernando Tesón, Collective Humanitarian Intervention, 17 MICH. J. INT’L L. 323, 335 (1996). 
collective mechanisms." While Tesón's analysis focuses primarily on the development of democracy as a rule through the experiences of nations and institutions in Europe and the Americas, his central thesis is enormously strengthened and far more compelling when considered against the revolutionary evolution of Africa's PDI and humanitarian intervention regimes, which surpass in every conceivable way those of any other region. ${ }^{7}$

Africa's intervention regime is derived from African state practice and treaty law fashioned in the continent. Consequently, this Article will examine several case studies where the preservation of democracy was a central rationale for intervention, employing a structural approach to highlight the normative development of the frameworks governing intervention in Africa. The Article is meant to be a snapshot rather than a comprehensive treatment of the law and practice of PDI in Africa. The central cases under review include the interventions by the Economic Community of West African States (ECOWAS) in Liberia, Sierra Leone, Guinea-Bissau, Guinea, Côte d' Ivoire, and Togo; the Mission for the Implementation of the Bangui Agreement (MISAB) in the Central African Republic (CAR); Southern African Development Community (SADC) operation in Lesotho; and African Union (AU) action in São Tomé and Príncipe. ${ }^{8}$ I also discuss the binding treaty law and security mechanisms of the AU, ECOWAS, and SADC that gave impetus to these interventions, ${ }^{9}$ and lay to rest questions about the

6 Id.; Fernando Tesón, HumantTARIAN INTERVENTION: AN INQUiRy INTO LAW AND MORALITY 185 (3d ed. 2006).

7 Levitt, The Law on Intervention, supra note 1, at 51.

8 For an analysis of the legality of several of the aforementioned interventions, see Jeremy Levitt, African Interventionist States and International Law, in AFRICAN INTERVENTIONIST STATES 15 (Oliver Furley \& Roy May eds., 2001) [hereinafter Levitt, African Interventionist States].

9 According to Article 26 of the Vienna Convention on the Law of Treaties, the international principle pacta sun servanda states that "every treaty in force is binding upon the parties to it and must be performed by them in good faith." Vienna Convention on the Law of Treaties art. 26, May 23, 1969, 1155 U.N.T.S. 331. Accordingly, all member states of the AU and ECOWAS are legally bound to abide by and perform their organizational rules/frameworks and duties, respectively. Since, as the following analysis will reveal, PDI and humanitarian intervention are essential conditions of both the constitutive acts and subsequent protocols that codified them, good faith compliance with them is essential. The only lawful way for a member state of the AU and/or ECOWAS to avoid being subject to PDI is to formally withdraw as a member of the organizations. There are provisions for withdrawal under articles 32 and 64 of the $\mathrm{AU}$ and ECOWAS constitutive acts, respectively. Charter of the Organization of African Unity art. XXXII, May 25, 1963, 479 U.N.T.S. 39; Treaty of the Economic Community of West African States, W. Afr. Countries, art. 64, May 28, 1975, 1010 U.N.T.S. 17. For an interesting and 
existence of a right to PDI insofar as it relates to the African region. ${ }^{10}$ In a sense the Article confirms Tom Farer's prediction that a group of democratic states might one day form a pact that:

in the event of an unconstitutional seizure of power in one pact member, others will continue to recognize the displaced elected officials as the only legitimate authority and, at their request, will take appropriate measures to reestablish constitutional government. If the officials are unable to communicate an appeal for assistance, the other pact members will consult and may by a vote of two-thirds or more of the member states choose to intervene militarily to restore democracy. ${ }^{11}$

As the forgoing analysis will reveal, the question is no longer whether states will form a pact to protect against unconstitutional seizures of government. Rather, the questions have become: At what stage of development is the "doctrine" of PDI? And when and under what circumstances might the threat or use of force be employed to safeguard democracy?

PDI is an evolving term and phenomenon, namely because the jus ad bellum, human rights law, and the emerging regime on democracy are in flux and because PDI seems to import several independent international law norms, including, among others, the doctrines of consent, self-determination, and humanitarian intervention. All of these doctrines intersect with the evolving norm of democracy or what Thomas Franck has termed the "democratic entitlement." 12 PDI appears to be evolving in five contemporaneous and perhaps interdependent ways, and the direction of its evolution will depend on the political factors that underlie future threats to democratically constituted governments, and the responses to them by states and their organizations. In Africa, a norm of PDI has crystallized through: (1) the consent doctrine (whether treaty-based or ad hoc); (2) customary regional

controversial analysis of the legality of treaty-based intervention, see David Wippman, TreatyBased Intervention: Who Can Say No?, 62 U. CHI. L. REV. 607 (1995).

10 See generally Oscar Schachter, The Legality of Pro-Democratic Invasion, 78 AM. J. INT'L L. 645 (1984).

"Tom Farer, A Paradigm of Legitimate Intervention, in ENFORCING RESTRAINT: COLLECTIVE INTER VENTION IN INTERNAL CONFLICTS 316, 332 (Lori Fisler Damrosch ed., 1993).

12 See Thomas M. Franck, The Emerging Right to Democratic Governance, 86 AM. J. INT'L L. 46 (1992) (arguing that representative democracy is evolving into an international legal obligation). See also Gregory H. Fox, The Right to Political Participation in International Law, 17 YALE J. INT'L L. 539, 607 (1992) (arguing that "parties to the major human rights conventions have created an international law of participatory rights"). See generally DEMOCRATIC GOVERNANCE AND INTERNATIONAL LAW (Gregory H. Fox \& Brad R. Roth eds., 2000). 
law; $;^{13}$ (3) the doctrine of self-determination (a jus cogens norm); (4) the emerging doctrine on democracy (emerging customary international law); and (5) perhaps, customary international law similar to the doctrine of humanitarian intervention. Although it is beyond the scope of this study to examine the development of all of these doctrines-all of which are controversial to varying degrees - their thorough examination in the context of PDI is sorely needed.

In the legal context, PDI may be defined in several ways, depending on the legal basis or authority used to justify it. Because the law is in flux, it is difficult to determine definitively which rules ultimately will comprise the legal authority of any norm of PDI; for this reason, this Article analyzes concrete state and regional organizational practices and treaty law in the only region that has adopted it as an unqualified right: Africa. ${ }^{14}$ State practice and treaty law in Africa indicate that, today, PDI is an intervention by a state, group of states, or regional organization in another state involving the threat or use of force in order to protect or restore a democratically constituted government (DCG) from unlawful and/or violent seizures of power, ${ }^{15}$ especially when the circumstances that underpin such seizures threaten a substantial part of a state's population with death or suffering on a grand scale.

PDI is preoccupied with serving the twin aims of protecting existing and future governments and peoples and preserving DCGs from illegal seizures of power from within rather than the "right of a state to use armed force to overthrow a despotic government in another country."16 PDI seeks to safeguard DCGs irrespective of their character, except for those that rise to power unconstitutionally, interfere with a people's right to self-determination, or acts unduly

13 While today PDI in Africa is based on consent and customary regional law, a norm of PDI in customary international law is fast developing and will likely not require prior consent of an embattled DCG-let alone a junta that has unlawfully seized power-as the notion of PDI is based on the illumination of democracy as an enforceable right.

14 The Latin America region has also made significant strides in developing a right of PDI through the Organization of American States (OAS). The U.S.-led OAS mission in Haiti in 1994 was the first regional organization to authorize the use of force to protect democracy. See generally Domingo E. Acevedo, The Haitian Crisis and the OAS Response: A Test of Effectiveness in Protecting Democracy, in ENFORCING RESTRAINT: COLLECTIVE INTERVENTION IN INTERNAL CONFLICTS, supra note 11 , at 119.

15 For purposes of this analysis, the term "democratically constituted governments" is broadly construed to mean those that are democratically elected or otherwise rise to power lawfully and/or those that are widely recognized as legitimate.

16 Schachter, supra note 10 , at 645 . 
repressive. ${ }^{17}$ Hence, in Africa, PDI appears to place a positive duty on states to remove threats to DCGs (e.g., unlawful rebellion and insurgency) and a negative duty on them not to support evil regimes or save repressive regimes from democratic revolution. Thus, PDI is meant to safeguard DCGs and legitimate regimes and accomplish the broader aims of maintaining peace, security, and law and order in states. In nascent and even intolerant democracies, ${ }^{18}$ PDI in Africa endeavors to maintain law and order to ensure an enabling environment for transition to authentic democracy. Again, it does not seek to establish democracy where it does not exist but to preserve democracy where it does.

The logic underpinning PDI in Africa focuses on how a regime came to power rather than its behavior while in power. Stated differently, under international law, an unpopular regime or state is no less entitled to exist free from external intrusion in its internal affairs than a popular one; however, as already noted, international law does not necessarily prohibit internal forces within a state from removing an unduly repressive regime. Nevertheless, DCGs that do not necessarily have a democratic orientation have benefited and will likely continue to benefit from PDI. The democracy-based interventions of the AU, ECOWAS, and SADC in budding democracies in Sierra Leone (1997), Guinea-Bissau (1998), Côte d'Ivoire (1998), Lesotho (1998), São Tomé and Príncipe (2003), and Togo (2005) are cases in point.

While there is no evidence in either African treaty law or state practice to conclude that a right of PDI exists against autocratic, corrupt, or politically as opposed to violently oppressive regimes-in contrast to

17 See G.A. Res. 2625 (XXV), at 123-24, U.N. Doc. A/8082 (Oct. 24, 1970) (Declaration on Principles of International Law Concerning Friendly Relations and Co-operation Among States in Accordance with the Charter of the United Nations); G.A. Res. 3314 (XXIX), art. 7, U.N. Doc. A/9619 (Dec. 14, 1974) (Definition of Aggression); G.A. Res. 42/22, TI 22, U.N. Doc. A/42/766 (Nov. 18, 1987) (Declaration on the Enhancement of the Effectiveness of the Principle of Refraining from the Threat or Use of Force in International Relations). In this context, the term "unduly repressive" connotes the systematic and violent repression of citizens of a state in order to prevent them from freely participating in government. This may include, among other things, the torture and killing of political opposition and other government detractors, stifling of political participation, unwillingness to conduct free and fair elections, rigging elections and silencing the media.

18 See generally Gregory H. Fox and George Nolte, Intolerant Democracies, 36 HARV. INT'L L.J. 1, 1 (1995) (exploring "the legal issues raised by the presence of anti-democratic actors in an otherwise generally 'free and fair' electoral process"). 
the purported American neorealist approach ${ }^{19}$-external intervention to simply unseat a bad DCG would be unlawful. Under Africa's current legal framework, a DCG or legitimate government would have to be unduly oppressive to its citizens for outside actors to invoke a right of PDI against it. However, if the international community were unwilling or unable to stop a government from being unduly repressive, external intervention aimed at preventing a population from forcefully removing a democratically constituted but repressive government would debatably interfere with their "democratic entitlement" their own human rights and their right to self-determination. ${ }^{21}$ In terms of Article 2(4) of the UN Charter, such action would arguably be an intervention against the sovereignty and political independence of a state engaged in a war of liberation-that is, a war aimed at establishing democracy and thwarting human atrocities. ${ }^{22}$ As Oscar Schachter noted, "No state today would deny the basic principle that the people of a nation have the right, under international law, to decide for themselves what kind of government they want, and that this includes the right to revolt and to carry on armed conflict between competing groups." ${ }^{23}$ It follows that DCGs may come to power through democratic processes or by democratic revolution when the behavior of a state is so egregious and repressive that its removal from power by indigenous or other forces is justified under international law.

Yet, it is often not clear when states and regional organizations in Africa have relied on democracy, human rights, or broader humanitarian considerations as opposed to national strategic interests as the basis for intervention; many of the civil conflicts that have necessitated intervention have had mixed motives and multiple objectives. Hence, for purposes of this analysis, it is important to briefly

19 The "neorealists see the use of force as an effective instrument to further other principles that they believe are integral to the UN Charter: self-determination, human rights, and above all democracy." However, the American neorealists school as, perhaps, best articulated by the Reagan Doctrine "reject any norm of international law that would forbid military assistance (including direct American intervention) to a prodemocratic insurgency fighting to overthrow a totalitarian government dependent upon external support." David J. Scheffer, Introduction: The Great Debate of the 1980s, in LOUIS HENKIN ET AL., RIGHT V. MIGHT: INTERNATIONAL LAW AND THE USE OF FORCE 1, 11 (2d ed. 1991).

20 See generally Franck, supra note 12.

21 See David Wippman, Practical and Legal Constraints on Internal Powersharing, in INTERNATIONAL LAW AND ETHNIC CONFLICT 211, 227-28 (David Wippman ed., 1998).

22 Oscar Schachter, International Law: The Right of States to Use Armed Force, 82 MICH. L. REV. 1620,1641 (1984).

23. Id. 
distinguish some of the major differences between PDI and humanitarian intervention because both doctrines are, at least in part, applicable to the case studies under review. Several of the interventions in this study could arguably have been justified under both paradigms. The next section contrasts PDI and humanitarian intervention.

\section{PRO-DEMOCRATIC INTERVENTION AND HUMANITARIAN INTERVENTION}

There are several notable similarities and differences between pro-democratic intervention and humanitarian intervention. ${ }^{24}$ In the African context, both derive their lawfulness from general international law, treaty law, and customary regional law and have the ultimate aims of protecting fundamental human rights and maintaining peace, security, stability, and law and order within states. Today, PDI is typically, but not exclusively, based on state consent (whether treaty-based or ad hoc) or authorized by the UN Security Council. Conversely, humanitarian intervention is not based on valid state consent, takes place without UNSC authorization, and is concerned primarily with curbing mass human suffering. Both PDI and humanitarian intervention can be conducted by states acting on their own initiative (e.g., Nigeria in Liberia), collectively through ad hoc groupings (e.g., MISAB in the CAR), and through regional organizations (e.g., ECOWAS in Sierra Leone). ${ }^{25}$ PDI in Africa does not raise the same "legal barriers" as humanitarian intervention because it does not abrogate the well-settled international law doctrines on state sovereignty, territorial integrity, and

24 Again, state practice and treaty law in Africa indicate that, today, PDI is an intervention by a state, group of states, regional organization, or the UN involving the threat or use of force in order to protect or restore a government from unlawful and/or violent seizures of power, especially when the circumstances underpinning such seizures threaten a substantial part of the state's population with death or suffering on a grand scale. I have defined humanitarian intervention as an "[i]ntervention in a state involving the use of force (U.N. action in Iraq and Somalia or ECOWAS action in Liberia and Sierra Leone [and Guinea-Bissau]) or threat of force (U.N. action in Haiti), where the intervener deploys armed forces and, at the least, makes clear that it is willing to use force if its operation is resisted-as it attempts to alleviate conditions in which a substantial part of the population of a state is threatened with death or suffering on a grand scale." Jeremy Levitt, Humanitarian Intervention by Regional Actors in Internal Conflicts: The Cases of ECOWAS in Liberia and Sierra Leone, 12 TEMP. INT'L \& COMP. L.J. 333, 335 (1998) [hereinafter Levitt, Humanitarian Intervention by Regional Actors].

25 However, there is a general consensus among states, scholars and practitioners that collective interventions are the most legally credible. 
nonintervention in the internal affairs of states. Again, today, PDI generally derives its legality from the doctrines of consent (ad hoc or treaty-based) but not yet from customary international law, wherein proponents of humanitarian intervention argue its legal basis.

Today, PDI and humanitarian intervention are also not deterred by a government's lack of effective control, i.e., its ability to validly consent to intervention. Whether a government is in effective control does not seem to seriously affect the legality and legitimacy of either type of intervention, though for different reasons. Humanitarian intervention is aimed at using force against a state to remedy grave human suffering. The goal of curbing ongoing human torment alone provides the legal basis for the intervention; state consent is moot. While PDI can be based on state consent, it seeks to safeguard DCGs irrespective of who is in de facto control because the intervention is on behalf of the government that acquired power democratically or is otherwise considered legitimate. Hence, even ousted regimes lacking effective control can make a valid request for intervention. ${ }^{26}$ Consequently, today, under Africa's new democracy and governance framework, de facto control no longer guarantees rebels or brokers of unconstitutional changes in power formal recognition or a seat at the table of power; when there have been unconstitutional regime changes, democratic governance appears to have attained a more prominent status than the effective control doctrine. ${ }^{27}$ As one analyst has noted, "[T]he statist version of legitimacy grounded on the logic of 'defactoism' or effectiveness ought to be abandoned as it has masked the worst violations of civil and political rights." ${ }^{28}$ Simply put, the democratic entitlement that underlies PDI is chiseling away at traditional conceptions of the effective control doctrine. ${ }^{29}$

African states and regional organizations, historically among the most conservative subscribers to the international law principles of state sovereignty, nonintervention, and territorial integrity today, have

${ }^{26}$ For example, Jean Bertrand Aristide's plea for U.S. intervention in Haiti in 1994 and Tejan Kabbah's request for ECOWAS action in Sierra Leone are cases in point.

27 See infra notes 287-298 and accompanying text for a discussion of Africa's new democracy and governance framework.

28 Reginald Ezetah, The Right to Democracy: A Qualitative Inquiry, 22 BROOK. J. INT'L L. 495, 526-27 (1997).

29 The three most authoritative legal sources that provide for a norm of PDI in Africa, and perhaps beyond, are found in African state practice, treaty law, and regional organizational practice; however, regional customary law, UN law, the doctrine of self-determination and the emerging doctrine on democracy also provide legal bases for PDI. 
adopted, operationalized, and acted under norm-creating mechanisms that are eroding traditional prohibitions on the use of force enshrined in the UN Charter and general international law. ${ }^{30}$ In fact, Africa is the first region to advance a comprehensive collective security regime. ${ }^{31}$ From a normative standpoint, the continent's intervention regime is more advanced and legally coherent than any other, including that of the North Atlantic Treaty Organization (NATO) - a fact that deserves greater attention in scholarly literature and among policy makers.

\section{WESTERN MYOPIA}

In international law and studies, Africa is viewed as a pariah-a basket case, not a marketplace. Most policymakers, international lawyers, and legal academics outside of the continent consider African states to be objects rather than subjects of international law. This fact explains why a significant portion of the wide body of literature on the law of the use of force and, more specifically, peacekeeping and intervention is heavily biased and flawed. ${ }^{32}$ The geopolitical, Eurocentric, and linear bias in Western legal academia, among others, is truly unfortunate. This predisposition is to a large degree based on a lack of interest, training, and regional expertise, particularly on the developing world, among Western intellectuals and international lawyers.

${ }^{30}$ Levitt, The Law on Intervention, supra note 1, at 51.

31 ld.

32 For example, at first glance, one of the most recent articles on democracy, sovereignty, and intervention appears to be solid and convincing; however, upon further review the article suffers from spotty research and apparent geo-political bias because it fails to examine the phenomena of intervention in Africa. Consequently it makes shamefully inaccurate conclusions. The article makes no mention of African state practice or treaty law developments nor references Africa's emerging democracy and intervention regime. See Andrew Coleman \& Jackson Maogoto, Democracy's Global Quest: A Noble Crusade Wrapped in Dirty Reality?, 28 SUFFoLK TRANSNAT'L L.REV. 175 (2005). These omissions are unacceptable given that, as the foregoing analysis will demonstrate, Africa has forwarded the world's most radical legal doctrine and security mechanisms to protect human rights and democracy. The authors of the article claim that "minimal international and regional procedures exist for responding to unconstitutional seizures of power." Id. at 197 . They assert that regional organizations "lack consensus on strengthening institutional capacity to promote democracy" and that "[a]ny departure from present practice [of non-intervention in the internal affairs of states] must survive the scrutiny of . . potentially hostile regional blocs in... Africa." Id. at 198 . Such analysis illuminates the linear bias and open ignorance about Africa's interventionist regime and contributions to international law, particularly the jus ad bellum. Unfortunately, such unintended bias and piecemeal analysis in international law is not the exception but the rule. 
As a result, topical discussions on PDI and humanitarian intervention in Africa are either uninformed or inadequately analyzed. More often than not, when analysts assess Africa's security landscape, they do so with a Eurocentric or, even worse, colonial voicepaternalistic and unaware. This phenomenon is unfortunate because it creates an environment for geo-political bias and analytically weak scholarship that often fails to acknowledge Africa's contribution to international law, particularly as it relates to jus ad bellum. ${ }^{33}$

The sections that follow assess the evolution of the PDI regime in Africa by analyzing African state practice, treaty law, regional organizational practice, and UN responses, or lack thereof, to them. Primary attention will be given to the ECOWAS, SADC, AU, and the states that compose them. As the analysis shows, PDI has been conducted by states acting in an ad hoc fashion or through regional actors.

\section{ECOWAS}

In 1975 ECOWAS was founded by treaty. ${ }^{34}$ Its main aim at the time was to spur economic integration and development in West Africa. ${ }^{35}$ Regional security was an important but not vital concern. ${ }^{36}$ ECOWAS later adopted a Protocol on Non-Aggression in 1978 and a Protocol Relating to Mutual Assistance on Defense in 1981. ${ }^{37}$ Neither the treaty nor the protocols empowered ECOWAS to launch peacekeeping missions (although the 1981 protocol did empower it to intervene in conflicts that were "externally engineered"). In 1989 the eruption of the Liberian Civil War tested ECOWAS; $;^{38}$ owing to international inaction, the organization was forced to intervene unilaterally (i.e., without Security Council authorization) to halt the conflict. ${ }^{39}$

33 See generally AFRICA: MAPPING NeW Boundaries IN INTERNATIONAL LAW (Jeremy I. Levitt ed., forthcoming 2006).

34 Levitt, The Law on Intervention, supra note 1, at 51.

35 Id.

36 Id.

37 Id.

38 Levitt, Humanitarian Intervention by Regional Actors, supra note 24, at 342-43. The civil war lasted from 1989 to 1997. JEREMY I. LEVITT, THE EVOLUTION OF DEADLY CONFLICT IN Liberia: From 'Paternalism' To State Collapse 206-10 (2005) [hereinafter LevitT, CONFLICT IN LIBERIA].

39 Levitt, Humanitarian Intervention by Regional Actors, supra note 24, at 346. 


\section{A. LIBERIA}

The Liberian Civil War began in 1989 when Charles Taylor and a group of so-called dissidents launched an attack against security personnel in Nimba County (located on the Liberia/Côte d'Ivoire border) and advanced toward the capital city of Monrovia. ${ }^{40}$ The group led by Taylor called themselves the National Patriotic Front of Liberia (NPFL). ${ }^{41}$ The NPFL recruited soldiers from many ethnic groups, foremost among them the Mano and Gio, and proceeded to crush the U.S.-backed Armed Forces of Liberia (AFL) of President Sergeant Samuel K. Doe. ${ }^{42}$ By May 1990 the NPFL controlled significantly more territory than Doe's collapsing regime, which had lost effective control of the state. ${ }^{43}$

Liberian security forces suffered enormous losses on the battlefield, which led Doe, who was facing certain defeat, to make several unsuccessful appeals to the people of Liberia, the United Nations, and the U.S. government for military assistance. ${ }^{44}$ Finally he appealed to ECOWAS to introduce a peace-keeping force into Liberia to "forestall increasing terror and tension" (i.e., to restore his decrepit government to power). ${ }^{45}$

On August 7, 1990, the ECOWAS Standing Mediation Commission ("Commission") agreed to establish an ECOWAS Ceasefire Monitoring Group (ECOMOG) in Liberia to halt the "wanton destruction of human life and property and ... massive damage ... being caused by the armed conflict to the stability and survival of the entire Liberian nation." ${ }^{\text {E6 }}$ ECOMOG was mandated to "restor[e] law and order to create the necessary conditions for free and fair elections." ${ }^{\prime 47}$ On

44 Id. at 243

45 Letter addressed by President Samuel K. Doe to the Chairman and Members of the Ministerial Meeting of the ECOWAS Standing Mediation Committee (July 14, 1990), in REGIONAL PEACEKEEPING AND INTERNATIONAL ENFORCEMENT: THE LibERIAN CRISIS 60-61 (M. Weller ed., 1994) [hereinafter THE LIBERIAN CRISIS].

46 See Economic Cmty. of West African States [ECOWAS], Standing Mediation Comm., Decision on the Cease-Fire and Establishment of ECOWAS Cease-Fire Monitoring Groups for Liberia, Decision A.DEC.1/8/90 (Aug. 7, 1990), reprinted in THE LIBERIAN CRISIS, supra note 45, at 67.

47 Id. at 68 (emphasis added). 
August 24, ECOMOG entered Liberia to forestall the killing, restore law and order, and prevent the state from descending into further anarchy. ${ }^{48}$ The NPFL, which by then controlled approximately 90 percent of the country, abducted and attacked ECOMOG forces upon their entry into the country. ${ }^{49}$

The situation worsened when, in September, Doe was murdered by the Independent National Patriotic Front, an NPFL splinter group. ${ }^{50}$ ECOWAS eventually stabilized the situation and nearly two years later, on November 19, 1992, the UN Security Council adopted Resolution 788, calling for the restoration of peace and a complete weapons embargo against Liberia and authorizing ECOWAS to enforce its terms. ${ }^{51}$ Ten months later, on September 22, 1993, the Security Council adopted Resolution $866,{ }^{52}$ which called for the creation of the UN Observer Mission in Liberia (UNOMIL), stating "that this would be the first peace-keeping mission undertaken by the United Nations in co-operation with a peace-keeping mission already set up by another organization, in this case the ECOWAS." ${ }^{33}$

I have argued elsewhere that the Security Council's stance affirmed the legality of the ECOWAS action and placed a retroactive de jure seal on its Liberia operation, confirming that the breakdown of law and order, protection of human rights, and the restoration of the rule of law were valid justifications for intervention by ECOWAS and later the UN.$^{54}$ ECOWAS's action was also arguably the first genuine case of humanitarian intervention. $^{55}$ At the very least, the approach by ECOWAS and the Security Council in this case confirmed that an intervention taken outside

so Id. at 207.

s1 Id. at 209; see also S.C. Res. 788, प1t 8, 10, U.N. Doc. S/RES/788 (Nov. 19, 1992).

52 S.C. Res. 866, U.N. Doc. S/RES/866 (Sept. 23, 1993).

53 Id.

54 Moreover, “[b]etween 22 January 1991 and 27 November 1996, the [Security] Council adopted fifteen resolutions directly relating to the situation in Liberia, in addition, the President of the Security Council issued nine statements in this connection." U.N. Dep't of Pub. Info., The United Nations and the Situation in Liberia, at 35, U.N. Doc. [ST/] DPV/1697/Rev.1 (1997). Almost every resolution and statement commended ECOWAS for its efforts, asked UN member states to support it financially, requested African states to contribute troops to its mission, and condemned attacks against it by rebel factions; not once was ECOWAS condemned for unlawful action or inappropriate conduct. Levitt, Humanitarian Intervention by Regional Actors, supra note 24, at 347.

ss See Levitt, Humanitarian Intervention by Regional Actors, supra note 24, at 350-51. 
the authority of the UN Charter to maintain law and order and protect human rights could indeed be lawful. ${ }^{56}$

Although it has yet to be widely recognized as such, the ECOWAS intervention was a watershed in the jus ad bellum and should not only be considered as the first authentic post-Cold War case of humanitarian intervention but also one aimed at creating an enabling environment for democracy. The fact that the Credentials Committee of the UN refused to accredit, recognize, or grant UN General Assembly representation to the so-called government of Charles Taylor in Liberia (until he won elections in 1997), ${ }^{57}$ despite the fact that he was in effective control of the state, speaks volumes about the rising status of the democracy regime and legitimacy of ECOWAS law in relation to the fledging status of the effective control doctrine. It also signals the validity of an intervention with pro-democratic components; the committee's decision not to accredit belligerents seems to have rested primarily "upon whether the applicant government was democratic and whether the applicant government originally came to power by overthrowing a democratic government." 58

\section{B. ECOWAS REVISED TREATY OF 1993}

In July 1993, three years into its peace creation mission in Liberia ${ }^{59}$ ECOWAS adopted the Revised Treaty of 1993 to, in part, provide a treaty basis for future peacekeeping. ${ }^{60}$ The contracting parties to the treaty

56 Some commentators have perhaps legitimately criticized the conduct of certain ECOMOG officials in Liberia, but none, in the author's view, have credibly challenged the legality of the intervention itself. The highly controversial operation of the North Atlantic Treaty Organization (NATO) in Kosovo came four years after the ECOMOG operation, making the latter the legitimate watershed case of humanitarian intervention and debatably PDI.

57 Jeremy I. Levitt, Illegal Peace?: Examining the Legality of Power-Sharing with Warlords and Rebels in Africa, 27 MicH. J. INT'L L. 495, 570 (2006).

58 Matthew Griffin, Accrediting Democracies: Does the Credentials Committee of the United Nations Promote Democracy Through Its Accreditation Process, and Should It?, 32 N.Y.U. J. INT'L L. \& POL. 725, 725-26 (2000). In fact, the Credentials Committee accredited representatives of Samuel Doe's government even though it lost power and Doe was killed in 1990. Id. at 746. According to Griffin, the central consequence of not being accredited is the inability to participate in the business of the General Assembly. Id. at 732.

59 Funmi Olonisakin, Conflict Management in Africa: The Role of the OAU and Sub-Regional Organizations, in INST. For SECURITY STUdIES, ISS MONOGRAPH 46, BUILDING STABILITY IN AFriCA: CHALlENGE FOR THE NEW MILLENNIUM (Feb. 2000), available at http://www.iss.co.za/ Pubs/Monographs/No46/Conflict.html (last visited Nov. 25, 2006).

60 Revised Treaty of the Economic Community of West African States, art. 58(f), July 24, 1993, 35 I.L.M. 660 [hereinafter Revised Treaty], reprinted in AFRICA: SELECTED DOCUMENTS ON 
affirmed and declared their adherence to the "maintenance of regional peace, stability, and security," 61 "recognition, promotion, and protection of human and people's rights," 62 and the "promotion and consolidation of a democratic system of governance in each member State."63 As part of its regional security aims, ECOWAS obligates itself, at the request of member states, to provide assistance for the observance of democratic elections ${ }^{64}$ and to "establish a regional peace and security observation system and peace-keeping forces where appropriate." 65 The treaty also provides for the adoption of protocols detailing additional provisions governing political cooperation and regional peace and stability. ${ }^{66}$

\section{Sierra Leone}

On May 25, 1997, approximately six months after the end of the civil war in Sierra Leone and shortly after the country's democratic elections, several junior military elements led by Major Johnny Koromah and the Revolutionary United Front (RUF) carried out a successful coup d'état against President Ahmed Tejan Kabbah's democratically elected government, forcing him to flee to Guinea. ${ }^{67}$ Before leaving Sierra Leone, however, Kabbah requested that Nigeria and ECOWAS intervene to forestall the conflict and restore constitutional order to the country. ${ }^{68}$ Additionally, the international community, including the UN and OAU, sternly condemned the coup. ${ }^{69}$ The OAU formally requested ECOWAS to intervene to restore Kabbah's regime to power, and UN Secretary-General Kofi Annan made similar pleas.

In response to Kabbah's request, on May 26, 1997, Nigeria (not ECOMOG) sent forces to Sierra Leone to forestall the conflict and restore constitutional order (i.e., return Kabbah to power). ${ }^{70}$ When they initially landed, Nigerian forces were met with strong resistance from the

CONSTITUTIVE, CONFlict AND SECURITY, HumanitaRian AND Judicial IsSUES 63, 95 (Jeremy I. Levitt ed., 2003) [hereinafter AFRICA: SELECTED DOCUMENTS].

64 Id. art. 58(2)(g), reprinted in AFRICA: SELECTED DOCUMENTS, supra note 60, at 63, 95.

65 Id. art. 58(2)(f), reprinted in AFRICA: SELECTED DOCUMENTS, supra note 60, at 63, 95.

s6 Id. art. 58(3), reprinted in AFRICA: SELECTED DOCUMENTS, supra note 60, at 63, 95.

67 Levitt, African Interventionist States, supra note 8, at 22.

68 ICISS, The Responsibility to Protect: Bibliography, supra note 4, at 105.

69 Levitt, Humanitarian Intervention by Regional Actors, supra note 24, at 365 .

70 Levitt, African Interventionist States, supra note 8, at 23. 
junta and were forced to retreat, but later they were able to push back the rebels and secure sections of the country. ${ }^{71}$ Likewise, in early August, pursuant to requests by member states of ECOWAS, General Sani Abacha, former Nigerian head of state and ECOWAS chairman, appears to have issued an executive directive authorizing an economic blockade against Sierra Leone to be enforced by ECOMOG. ${ }^{72}$ On August 30, during the Twentieth Summit of ECOWAS in Abuja, ECOWAS officially mandated ECOMOG to enforce sanctions against the junta and restore law and order to the country. ${ }^{73}$ On October 8 , the UNSC supported these various efforts by adopting Resolution 1132, which deplored the coup and the junta's unwillingness to restore the "democratically elected Government" and constitutional order. ${ }^{74}$ Acting under its Chapter VII enforcement powers, the UNSC also demanded that the junta "relinquish power" and "make way for the restoration of the democratically elected Government and a return to constitutional order," ${ }^{75}$ and strongly supported ECOWAS efforts to restore Kabbah's government to power. ${ }^{76}$ Acting under its Chapter VIII authority, the UNSC sanctioned ECOWAS to enforce an arms and petroleum embargo and travel restrictions against the junta and halt, inspect, and verify the cargo and destinations of all inward-shipping vessels. ${ }^{77}$

On February 5, 1998, "responding to an attack by junta forces on their position at Lungi, ECOMOG launched a military attack on the junta," which led to its removal from power and expulsion from Free Town on February 12.78 By early March, "ECOMOG [had] established itself successfully across most of the country." 79 On March 10, Kabbah returned to the capital city, Free Town, to resume his position as president of Sierra Leone. ${ }^{80}$ The leaders of Nigeria, Guinea, Mali, and Niger and the vice-president of the Gambia accompanied him. ${ }^{81}$

${ }^{71}$ Levitt, Humanitarian Intervention by Regional Actors, supra note 24, at 366.

72 Levitt, African Interventionist States, supra note 8, at 23.

73 ld.

74 S.C. Res. 1132, pmbl., U.N. Doc. S/RES/1132 (Oct. 8, 1997).

75 Id. II 1.

76 Id. If 3. The U.N. Security Council called on the international community to support and cooperate with the ECOWAS operation. Id. II 18.

77 Id. 18.

78 The Secretary-General, Fourth Report of the Secretary-General on the Situation in Sierra Leone, II 6, U.N. Doc. S/1998/249 (Mar. 18, 1998).

79 Id. II 19.

80 Levitt, African Interventionist States, supra note 8, at 23.

81 Id. 
From a legal standpoint, it is important to note that there were two separate interventions in Sierra Leone: the first was taken under the authority of the Republic of Nigeria; the second was undertaken by ECOWAS. While each intervention arguably had multiple legal bases, the primary rationale for both was to restore the democratically elected government of Tejan Kabbah.

The Nigerian intervention in Sierra Leone was justifiable on several legal bases; ${ }^{82}$ however, it was the first PDI by a single state-one that was applauded by the whole of the international community. The ECOWAS intervention in Sierra Leone was also lawful for several reasons; ${ }^{83}$ however, it should be regarded as the most authoritative case of PDI by a regional organization, given the swiftness with which it took place and the global unanimity concerning its legitimacy. ${ }^{84}$ Both interventions were retroactively sanctioned through UNSC Resolution 1132.85

The ECOWAS intervention into Sierra Leone debatably could be classified as both a humanitarian intervention and PDI. I have stated elsewhere that although Kabbah requested outside intervention while fleeing to Guinea, his regime was still in effective control of the state, ${ }^{86}$ even if it was not in control of Free Town at that time. Moreover, Kabbah's government "was still recognized as the de jure government by the whole of the international community." ${ }^{87}$ More importantly, however, the civilian population of Sierra Leone continued to recognize Kabbah as their leader and actively protested and took up arms against the junta. ${ }^{88}$ Since it appears that Kabbah lawfully consented to the intervention, by definition it cannot serve as an example of humanitarian intervention. I nonetheless have argued:

Shortly after the coup, the situation in the country became chaotic. Yet it was not consumed by anarchy nor, arguably, at this juncture, had the junta and RUF committed human rights abuses that would have warranted humanitarian intervention. Nevertheless, ECOWAS could lawfully invoke a right of humanitarian intervention because

82 For an in-depth analysis of the legal bases for the Nigerian intervention, see id. at 22-26.

Id.

84 Id.

85 S.C. Res. 1132, supra note 74.

86 Levitt, African Interventionist States, supra note 8, at 22-24.

87 Id.

88 "This is perhaps the first time in contemporary African history that well over 95 per cent of the civilian population of a state actively resisted the toppling of a democratically elected regime and refused to co-operate with and recognize its illegal incumbent." Id. 
the democratic government of Sierra Leone was illegally and violently dislodged against the will of its civilian populace, ${ }^{89}$ who because of their opposition to the junta were threatened with death and suffering on a grand scale. ${ }^{90}$ Moreover, civilian opposition by way of armed resistance and nationwide employment strikes against the junta intensified the situation and caused the state infrastructure to collapse. Had ECOMOG not intervened, fighting between the junta and the RUF on the one hand and the Kamajors and other civilians loyal to Kabbah on the other would have escalated, resulting in untold destruction and loss of life. ${ }^{9 \mathrm{t}}$

While the ECOWAS intervention in Sierra Leone arguably would not qualify as a humanitarian intervention under a strict interpretation of the term, I defined it broadly enough to include what I identified as an emerging practice of PDI. I included the unlawful and violent seizure of DCGs against the will of a threatened civilian populace within the paradigm of humanitarian intervention because of the inseparable and interdependent link among violent coups d'état, civil war, and massive human rights violations, and because when the coup in Sierra Leone took place, there was not sufficient state practice or treaty law to claim that an independent right of PDI existed. ${ }^{92}$ Nevertheless, statements made by General-Secretary Annan were instructive here because they seemed to validate the emergence of a pro-democratic right of intervention when DCGs are overthrown. In the wake of the coup in Sierra Leone, Annan commented, "Africa can no longer tolerate, and accept as faits accomplis, coups against elected government, and the illegal seizure of power by military cliques, who sometimes act for

89 For more on this issue see Levitt, Humanitarian Intervention by Regional Actors, supra note 24, at 369-71. See also Jeffrey C. Tuomala, Just Cause: The Thread that Runs So True, 15 Dick. J. INT'L L. 1 (1994)(examining the 1989 U.S. intervention in Panama and discussing just war theory in this context).

90 "However, without a genuine threat of death or grand suffering to the domestic populace of a state, it has yet to be resolved whether a right to pro-democratic intervention exists. Nevertheless, based on the diversity of justifiable circumstances that led to the recent AU action in São Tomé and Príncipe, the U.S.-led UN mission in Haiti, the ECOMOG operations in Sierra Leone, Guinea-Bissau and Togo, MISAB intervention in the CAR, and SADC operation in Lesotho, it appears a pro-democratic norm that does not include such suffering and falls outside of the purview of humanitarian intervention is fast developing." Levitt, African Interventionist States, supra note 8, at 26.

91 Id. at 25-26.

92 Again, this labeling was based on state practice in the Africa region, the nexus between state collapse and human rights violations in the continent, and a lack of consensus inside and outside of Africa as to the existence of a norm of PDI. 
sectional interests, sometimes simply for their own," and hence, must take whatever action is necessary to restore constitutional order. ${ }^{93}$

Today, there appears to be sufficient state practice and treaty law development to demonstrate the ripening of an independent norm of PDI, which "falls outside the scope of humanitarian intervention, and may be better associated with the doctrine of self-determination" or the emerging right of democracy. ${ }^{94}$ In this case, ECOWAS action in Sierra Leone was a watershed case in the shift toward the hardening of a PDI norm. UN practice seems to support this assertion, given its avid support of ECOWAS action through Resolution 1132 and the decisions of the UN Credentials Committee, which refused to accredit UN General Assembly representation for the supposed government of Johnny Paul Koromo in Sierra Leone in 1997 (after he overthrew Kabbah's democratically elected regime), ${ }^{95}$ despite the fact that Koromo was in de facto control of the state. As was the case in Liberia, the decision not to credit insurrectionists in Sierra Leone seems to have rested on whether the applicant government was democratic and whether it came to power by toppling a democratic government. ${ }^{96}$ Hence, the case of Sierra Leone arguably signaled the first clear case of a shift in de lege ferenda toward a right of PDI, and the second time (the first was Haiti) that the acceptability of a government would be judged by international actors, perhaps evidencing the "rise of popular sovereignty. ${ }^{, 97}$

\section{THE ECOWAS CONFLICT FRAMEWORK}

In October 1998, some fourteen months after the intervention in Sierra Leone, ECOWAS adopted a binding mechanism to allow for interstate collaboration in the collective management of regional security: the Framework for the Mechanism for Conflict Prevention,

93 Press Release, Secretary-General, Secretary-General Calls for Efforts to Unleash African "Third Wave" Based on Democracy, Human Rights, and Sustainable Development, U.N. Doc. SG/SM/6245/Rev.1 AFR/9/Rev.1 (June 2, 1997), available at http://www.un.org/News/ Press/docs/1997/19970602.sgsm6245.r1.html.

94 Levitt, Humanitarian Intervention by Regional Actors, supra note 24, at $337 \mathrm{n} .18$.

95 Griffin, supra note 58, at 725 . In fact, despite its removal from power, the Credentials Committee "accredited the delegation of the deposed, democratically elected government of President Kabbah of Sierra Leone." Id. at 747.

96 Id. at 725-26.

${ }^{97}$ See Louis E. Fielding, Taking the Next Step in the Development of New Human Rights: The Emerging Right of Humanitarian Assistance to Restore Democracy, 5 DUKE J. COMP. \& INT'L L. 338 (1995). 
Management, Resolution, Peacekeeping and Security ("Framework"). ${ }^{98}$ The Framework sets out an elaborate scheme for ECOWAS-ECOMOG enforcement operations, including a coherent command and control structure. ${ }^{99}$ It calls for the creation of an ECOWAS Mediation and Security Council to authorize all forms of military intervention.

Regarding internal conflicts that are sustained from within, Paragraph 46 of the Framework provides for military intervention by ECOWAS when crises (1) threaten to trigger a humanitarian disaster, ${ }^{100}$ (2) pose a serious threat to peace and security in the subregion, ${ }^{101}$ and (3) erupt following the overthrow or attempted overthrow of a democratically elected government. ${ }^{102}$ Except for the new African Union, no other regional organization has laid down a normative framework for unilateral military intervention. ${ }^{103}$ Furthermore, Paragraph 52 of the Framework provides that ECOMOG may undertake military operations for peacekeeping, ${ }^{104}$ humanitarian intervention in support of humanitarian actions, ${ }^{105}$ and the enforcement of sanctions and embargos. ${ }^{106}$ ECOWAS is thus the first regional arrangement to codify both humanitarian and pro-democratic rights of intervention.

One year after the ECOWAS intervention in Sierra Leone, its capacity to maintain peace and security and law and order in West Africa was tested again by the conflict in Guinea-Bissau.

98 Framework Establishing the ECOWAS Mechanism for Conflict Prevention, Management, Resolution, Peacekeeping and Security, July 24, 1998 [hereinafter ECOWAS Conflict Management Framework], reprinted in AFRICA: SELECTED DOCUMENTS, supra note 60, at 285.

99 Id., reprinted in AFRICA: SELECTED DOCUMENTS, supra note 60, at 285.

${ }^{100}$ Id., II 46(i), reprinted in AFRICA: SELECTED DOCUMENTS, supra note 60, at 285, 298.

${ }^{101}$ Id., II 46(ii), reprinted in AFRICA: SELECTED DOCUMENTS, supra note 60, at 285, 298.

${ }^{102}$ Id., II 46(iii), reprinted in AFRICA: SELECTED DOCUMENTS, supra note 60, at 285, 298 (emphasis added).

${ }^{103}$ Unilateral military intervention means the willingness to, if necessary, employ enforcement measures without authorization from the UN Security Council. It does appear that in 2001 the OAS codified a right to democracy within its member states that is enforceable through PDI; however, it is not clear whether prior authorization from the UN Security Council is required. See Inter-American Democratic Charter, arts. 1, 17- 18, Sept. 11, 2001, 40 I.L.M. 1289; Organization of American States [OAS], Table Comparing the Texts of the Inter-American Democratic Charter-draft Resolution Rev. 7, The OAS Charter, and Resolution AG/RES. 1080 (XXI-O/91), on Representative Democracy, OAS Doc. GT/CDI-1/01 (July 16, 2001), available at http://www.oas.org/charter/docs/tables_en.htm.

${ }^{104}$ ECOWAS Conflict Management Framework, supra note 98, II 52(ii), reprinted in AFRICA: SELECTED DOCUMENTS, supra note 60, at 285, 287.

${ }^{105}$ Id. II 52(iii), reprinted in AFRICA: SELECTED DOCUMENTS, supra note 60, at 285, 287.

${ }^{100}$ Id. II 52(iv), reprinted in AFR ICA: SELECTED DOCUMENTS, supra note 60, at 285, 287. 


\section{Guinea-Bissau}

On June 7, 1998, the democratically elected government of President Bernardo Nino Vieira was threatened with a mutiny by highranking officers of the Armed Forces of Guinea-Bissau, led by Army Chief of Staff Ansoumane Mane. ${ }^{107}$ The mutiny was initiated after President Vieira fired Mane for not investigating claims that his officers were smuggling arms to the Casamance rebels in southern Senegal. ${ }^{108}$ The mutineers also opposed government plans to reduce the military by 50 percent from its 1996 strength of twenty thousand. ${ }^{109}$ By the end of June, fighting between the mutineers and loyalist forces resulted in the deaths of several hundred civilians and caused over two hundred and fifty thousand persons to be displaced. ${ }^{110}$ Nevertheless, Vieira's government always remained in effective control of the state. ${ }^{111}$

At the request of President Vieira and pursuant to bilateral defense pacts, Senegal and Guinea intervened to quell the mutiny, evacuate their nationals and those of other countries, and restore security and constitutional legality to the country. ${ }^{112}$ They did not intervene to enforce the peace but rather to safeguard Vieira's government. ${ }^{113}$ Vieira also requested that ECOWAS deploy ECOMOG in the country. ${ }^{114}$ During the eighteenth Foreign Ministers' Conference on Security in Abidjan, Côte d'Ivoire, from June 30 to July 3, ECOWAS foreign ministers made tentative plans to intervene in Guinea-Bissau to restore law and order to the country. ${ }^{115}$

However, after a series of peace talks sponsored by the ECOWAS Committee on Guinea-Bissau and the Community of Portuguese Speaking Countries (CPLP) between August and December 1998, President Vieira and chief mutineer Mane agreed to the deployment of ECOMOG to monitor the peace and the institution of a

\footnotetext{
${ }^{107}$ Manes' Men: An Army Mutiny Has Quickly Become a Security Problem for the Neighbouring States, AFr. CONFIDENTIAL, June 26, 1998, at 3.

${ }^{108} \mathrm{Id}$.

109 Id.

${ }^{110}$ Levitt, African Interventionist States, supra note 8, at 27.

III Id.

112 Senegal and Guinea immediately sent 1,300 and 400 troops, respectively, to the country. Id.

$113 \mathrm{Id}$.

114 ECOWAS Puts Out Plan to End Bissau Mutiny, Panafrican News Agency, July 5, 1998, available at LEXIS (search "News, All (English, Full Text)" database for "ECOWAS puts out plan").

11 Levitt, African Interventionist States, supra note 8, at 27.
} 
government of National Unity. ${ }^{116}$ The ECOMOG force would provide security along the Guinea-Bissau/Senegal border, keep the warring parties apart, guarantee free access to humanitarian organizations attempting to provide humanitarian relief to the domestic population, and ensure that the conflict did not have any destabilizing effects on the subregion. ${ }^{117}$ The Abuja Accord specifically provided for the deployment of ECOMOG to replace the Senegalese and Guinean contingents. ${ }^{118}$ On December 26, 1998, less than a week before ECOMOG was to be deployed in Guinea-Bissau, the UN Security Council adopted Resolution 1216, which "welcomes" the role of ECOMOG in the implementation of the accord; "approves" the ECOMOG mandate; "commends" ECOWAS efforts to restore peace and security; and "affirms" that "the ECOMOG interposition force may be required to take action [i.e., use force]... in the discharge of its mandate." 119 Between December 1998 and March 1999, Benin, the Gambia, Niger, and Togo deployed approximately six hundred ECOMOG troops in Guinea-Bissau ${ }^{120}$ to "guarantee security along the Senegalese/Guinea-Bissau border, keep the warring parties apart and guarantee free access to humanitarian organizations."121

It is important to note that, like the interventions in Sierra Leone, there were two separate interventions in Guinea-Bissau: the first was by Senegal and Guinea; the second, by ECOWAS. While each intervention had multiple legal bases, ${ }^{122}$ the primary rationale for each was to protect Vieira's controversial yet democratically elected government from being overthrown by the military. ${ }^{123}$

The central aim of the Senegalese and Guinean intervention was quashing the mutiny, and the intervention was generally applauded by political elites inside and outside of Africa. The consent-based intervention served as yet another example of the willingness of African states to challenge unconstitutional regime changes. The swiftness and

\footnotetext{
116 Id. at $28-29$.

117 The Secretary-General, Report of the Secretary-General Pursuant to Security Council Resolution 1216 Relative to the Situation in Guinea-Bissau, I 3(c), U.N. Doc. S/1999/294 (Mar. 17, 1999).

${ }^{118}$ Id. TI 3(b), 11-12. The second round of peace talks which produced the Abuja Accord were held in Abuja, Nigeria, on November 1, 1998. Id. II 3.

119 S.C. Res. 1216, भा 3, 4, 6, U.N. Doc. S/RES/1216 (Dec. 21, 1998).

${ }^{120}$ The Secretary-General, supra note 117, II 11 (Mali had promised an additional 125 troops).

121 S.C. Res. 1216, II 3(c), 4, 6, U.N. Doc. S/RES/1216 (Dec. 21, 1998).

122 For an in-depth analysis of the legal bases for the Senegalese, Guinean and ECOWAS intervention in Guinea-Bissau, see Levitt, African Interventionist States, supra note 8, at 28-38.

123 Levitt, African Interventionist States, supra note 8, at 26-31.
} 
robust nature of the intervention by Senegal and Guinea was an early sign of a trend toward PDI in Africa.

The situation in Guinea-Bissau threatened Vieira's government and posed a genuine threat of death and grand suffering to the civilian population; hence, the ECOWAS operation safeguarded Vieira's regime and Bissauns and likely prevented civil war. ECOWAS leaders clearly realized that the preservation of weak and arguably authoritarian but democratically constituted governments was fundamental to long-term peace and security in the subregion. ${ }^{24}$ Like the cases of Sierra Leone and Haiti, ${ }^{125}$ the Bissaun case also confirmed that an intervention taken to preserve democracy could be lawful and legitimate. This assertion is further supported by the UN's formal sanction of the operation as well as the lack of any formal protest as to its lawfulness.

In the wake of its peace operations in Liberia, Sierra Leone, and Guinea-Bissau, ECOWAS established a new conflict mechanism to prevent, manage, and resolve future conflicts.

\section{THE ECOWAS CONFLICT PROTOCOL}

In December 1999, approximately one year after the introduction of the Framework and the launch of the Guinea-Bissau operation, ECOWAS adopted the Protocol Establishing the Mechanism for Conflict Prevention, Management, Resolution, Peacekeeping and Security ("Conflict Protocol"), which aims to implement further Article 58 of the Revised Treaty. ${ }^{126}$ The Conflict Protocol recognizes that peace, security, stability, democracy, and good governance are central to the development of the West African region; ${ }^{127}$ one of its key objectives is to protect member states from being "affected by the overthrow or attempted overthrow of a democratically elected government." 228 It also affirms its commitment to promoting and consolidating democratic government and institutions in each member state, supporting processes for the political

\footnotetext{
124 See generally Fielding, supra note 97, at 329.

125 See generally Acevedo, supra note 14, at 119 (providing an authoritative analysis of the legality of the OAS response to the 1993 Haitian crisis).

${ }^{126}$ Protocol Relating to the Mechanism for Conflict Prevention, Management, Resolution, PeaceKeeping and Security, pmbl., ECOWAS Doc. A/P10/12/99 (Dec. 10, 1999), available at http://www.sec.ecowas.int/sitecedeao/english/ap101299.htm [hereinafter ECOWAS Conflict Protocol], reprinted in AFRICA: SELECTED DOCUMENTS, supra note 60, at 259, $261-264$.

127 Id, reprinted in AFRICA: SELECTED DOCUMENTS, supra note 60, at 259, 261-64.

${ }^{128}$ Id., reprinted in AFRICA: SELECTED DOCUMENTS, supra note 60, at 259, 261-64.
} 
restoration of collapsed governments or those that have been seriously eroded, and protecting fundamental human rights and freedoms. ${ }^{129}$

The ECOWAS Conflict Protocol also aims to prevent, manage, and resolve internal and interstate conflict-and here it states that Paragraph 46 of the Framework governs these matters. ${ }^{130}$ Like the Framework, Article 22 of the Conflict Protocol states that peacekeeping and the restoration of peace, humanitarian intervention during humanitarian disasters, and the enforcement of sanctions, including embargoes, are key responsibilities of ECOMOG. ${ }^{131}$

Article 25 of the Conflict Protocol complements Paragraph 46 of the Framework, stating that ECOWAS may take enforcement action in internal conflicts: (1) that "threaten to trigger a humanitarian disaster or that pose a serious threat to peace and security in the sub-region;" (2) where there has been a "serious and massive violation of human rights and the rule of law;" and (3) when there has been an "overthrow or attempted overthrow of a democratically elected government." 132 Invoking these considerations, ECOWAS sought to establish an ECOMOG force along the border areas of Guinea and Liberia in December 2000 to prevent skirmishes between the two countries from escalating into full-blown conflict. ${ }^{133}$ The ECOWAS conflict mechanism also served as first responder to the crisis in Côte d'Ivoire in October 2000 .

\section{Côte d'Ivoire}

In October 2000 Côte d' Ivoire's current president, Laurent Gbagbo, was declared the winner of a bitterly contested national election that was decided in his favor by the country's Supreme Court. ${ }^{134}$ Since then he has not been able to bring sustainable peace to the embattled nation. ${ }^{135}$

${ }^{129}$ Id. arts. 2, 45, reprinted in AFRICA: SELECTED DOCUMENTS, supra note 60, at 259, 264, 281.

130 Id. art. 3, reprinted in AFRICA: SELECTED DOCUMENTS, supra note 60, at 259, 265.

131 Id. art. 22, reprinted in AFRICA: SELECTED DOCUMENTS, supra note 60, at 259, 272 (emphasis added).

${ }^{132}$ Id. art. 25, reprinted in AFrICA: SEleCted Documents, supra note 60, at 259, 274 (emphasis added).

${ }^{133}$ Decision Dec. 4/12/00 Establishing a Force of ECOMOG Armed Monitors along the Border Areas of Guinea and Liberia (Dec. 16, 2000), http://www.sec.ecowas.int/sitecedeao/english/ adec04122000.htm.

${ }^{134}$ Levitt, The Law on Intervention, supra note 1, at 54.

${ }^{135} \mathrm{Id}$. 
The root of the current crisis in Côte d'Ivoire dates back to September 2002 when approximately eight hundred discontented soldiers calling themselves the Patriotic Movement of Côte d'Ivoire overthrew Gbagbo's government and attacked military installations in the commercial, administrative, and diplomatic center, Abidjan, and in the second largest city, Bouake. ${ }^{136}$ The rebels feared being dismissed from the army for disloyalty, ${ }^{137}$ and they wanted to challenge the government's so-called prejudicial "Ivoirité" policy, which required all inhabitants of the country to carry identification cards prior to the issuance of a ballot in all national and regional elections. ${ }^{138}$ The revolt ultimately divided the country between the rebel-controlled north and the loyalist south. ${ }^{139}$ As a result, Gbagbo's government lost de facto control of the country.

France, which had twenty thousand nationals in the country, dispatched paratroopers to Côte d'Ivoire to protect its citizens after initial hostilities broke out in $2000 .^{140}$ It provided transportation and security to an ECOWAS mediation team that met with the junta. ${ }^{141}$ The mediation team communicated the organization's position of not supporting the overthrow of DCGs and threatened to deploy ECOMOG in the country if the warring parties could not resolve the situation, including a return to constitutional order. ${ }^{142}$

In October 2002, at the request of President Gbagbo, ECOWAS, acting under the authority of its Conflict Protocol, instituted a peacekeeping force to monitor the cease-fire agreement in Côte d'Ivoire. ${ }^{143}$ Efforts by ECOWAS, the United Nations, France, and the African Union

${ }^{136}$ The Nightmare Scenario: An Army Rebellion May Send the Once-Prosperous Country Down the Same Road As Its Unstable Neighbors, AFr. ConfIDENTIAL, Sept. 27, 2002, at 1 [hereinafter The Nightmare Scenario].

${ }^{137}$ Id. But see Ivory Coast Troops Prepare to Attack Rebels Holding Major City, N.Y. TimEs, Sept. 22,2002 , at 13 (showing that there is a discrepancy in the number of rebels in the group-the N.Y. TIMES cites 750 men compared to AFRICA CONFIDENTIAL's 789 men).

${ }^{138}$ The Melting Pot Cracks, ECONOMIST, Oct. 5, 2002, at 64.

139 The Nightmare Scenario, supra note 136, at 2.

${ }^{140}$ Alistair Thomson, West African Ministers Set to Talk to Ivorian Rebels, ReUTERS News, Oct. 3, 2002, available at LEXIS (search the "Reuters News" database for "'West African Ministers' and Thomson"). See also The Nightmare Scenario, supra note 136, at 1.

${ }^{14)}$ Cote d'Ivoire; With No Ceasefire in Ivory Coast, War Threat Looms, AFRICA NEws, Oct. 6, 2002, available at LEXIS (search "News, All (English, Full Text)" database for "No Ceasefire in Ivory Coast").

${ }^{142}$ Cote d'Ivoire Fighting Continues to Pose Significant Threat to Government, W. AFr. DEFENSE \& FOREIGN AFFAIRS DAILY, Oct. 8, 2002, available at LEXIS (search "News, All (English, Full Text)" database for "Cote d'Ivoire Fighting Continues").

${ }^{143}$ Levitt, The Law on Intervention, supra note 1, at 54-55. 
culminated in the Linas-Marcoussis Agreement of January 2003.:44 In early February 2004 the UN Security Council adopted Resolution 1527, which fully supported efforts by ECOWAS and France to "promote a peaceful settlement of the conflict" and empowered the ECOWAS mission in Côte d'Ivoire to stabilize the nation. ${ }^{145}$ The resolution authorized France to support ECOWAS. ${ }^{146}$ In late February the Security Council adopted Resolution 1528 establishing the UN Operation in Côte d'Ivoire (UNOCI) to guarantee the terms of the peace agreement. ${ }^{147}$ ECOWAS forces were integrated into UNOCI, and French peacekeeping forces were authorized to "use all necessary means" to support the UNOCI mission. ${ }^{148}$

After the ECOWAS action in Liberia, Sierra Leone, GuineaBissau and Côte d'Ivoire, the organization sought to develop a systematic approach to promoting and protecting democracy in its member states and adopted a bold protocol in this regard.

\section{E. The ECOWAS DEMOCRACY PROTOCOL}

The ECOWAS Protocol on Democracy and Good Governance ("Democracy Protocol") is the most recent articulation of West Africa's approach to the creation, preservation, and protection of democracy. ${ }^{149}$ It recognizes that in order for ECOWAS to be an effective peace broker, it must pay special attention to the inherent linkages among "internal crises, democracy and good governance, the rule of law, and human rights." In In this context, the ECOWAS Democracy Protocol requires ECOWAS member states to establish mechanisms that promote, protect, and enforce democracy and human rights as a matter of law and policy and obligates them to enshrine democracy as, in Samuel Barnes's phrase, "an institutionalized process of decision making and societal learning,

\footnotetext{
144 Id.

${ }^{145}$ S.C. Res. 1527, U.N. Doc. S/RES/1527 (Feb. 4, 2004).

$146 \mathrm{ld}$.

147 S.C. Res. 1528, Il 1, U.N. Doc. S/RES/1528 (Feb. 27, 2004).

${ }^{148}$ Id. II 8.

${ }^{149}$ ECOWAS, Protocol A/SP1/12/01 on Democracy and Good Governance, Supplementary to the Protocol Relating to the Mechanism for Conflict Prevention, Management, Resolution, Peacekeeping and Security (Dec. 21, 2001), available at http://www.sec.ecowas.int/sitecedeao/ english/protocoles/Protocol\%20on\%20good-governance-and-democracy-rev-5EN.pdf [hereinafter ECOWAS Protocol on Democracy and Good Governance].

${ }^{150}$ Id. at pmbl.
} 
not a substantive formula for a regime."151 The Democracy Protocol also forbids all cruel, inhuman, and degrading treatment of civilians and combatants during times of war and peace. ${ }^{152}$ It specifically endorses the notion of empowering the ECOWAS Court of Justice to adjudicate cases "relating to violations of human rights" after domestic remedies have been exhausted ${ }^{153}$ and deems as essential the elimination of "all forms of discrimination and harmful and degrading practices against women." 154 Last, it confirms that in West Africa, democracy is an entitlement to be respected, promoted, and preserved by PDI, if necessary.

One month before it received its eighth ratification (Niger in March 2005-nine are needed for it to enter into force), ECOWAS's commitment to peace, security and democracy was tested in Togo.

\section{Togo}

On February 5, 2005, after thirty-eight years of authoritarian rule, ${ }^{155}$ President Gnassingbe Eyadema of Togo died of a heart attack, leaving a power vacuum that led to a legislature-backed unconstitutional transition of power to his son, Faure Gnassingbe Eyadema. ${ }^{156}$ The succession was backed by the army, which sealed the country's borders shortly after Eyadema's death. ${ }^{157}$ The Togo Constitution provides that the president of the National Assembly is to succeed the president in the event of death or incapacity until special elections are held. ${ }^{158}$ However, the army redirected National Assembly Speaker Fanbore Natchaba's plane to Benin in a bid to keep him from claiming the presidency. ${ }^{159}$ On February 6, 2005, Togo's Assembly elected Faure president of the National Assembly, which under Togolese law meant that he was to succeed to the presidency. ${ }^{160}$ The assembly also passed a constitutional amendment allowing him to fulfill his father's term, which was to last

${ }^{151}$ Samuel H. Barnes, The Contribution of Democracy to Rebuilding Post Conflict Societies, 95 AM J. INT'L L. 86, 89 (2001).

${ }^{152}$ ECOWAS Protocol on Democracy and Good Governance, supra note 149, art. 22(2).

153 ld. art. 39.

${ }^{154}$ Id. art. 40.

155 Jonathan Clayton, Togo "Military Coup" Hands Leadership to President's Son, TimES (UK), February 7, 2005, at 31.

${ }^{136}$ Gnassingbe Eyadema Dies, 42 AFR. REs. BULL. 16,096 (2005).

157 Id.

158 Id.

${ }^{159} I d$.

${ }^{160}$ Id. See also The Struggle Continues in Togo, AfR. ANALYSIS, Feb. 11, 2005, 1, available at ProQuest (search the Ethnic Newswatch database for "Struggle Continues Togo"). 
until 2008. ${ }^{161}$ This unconstitutional maneuver was directed by General Zakary Nandja, Chief of Staff of the Forces Armées Togolaises. Nandja had been a close advisor to President Eyadema and shared his Kabyé ethnic background. ${ }^{162}$ The strategy was also allegedly engineered by Esso Solitoki, the Law Commission president. ${ }^{163}$

Ethnic tensions were the root cause of the "coup."164 Simply stated, the army leadership wanted to maintain power in the hands of the Kabyé ethnic group. ${ }^{165}$ The military is reportedly 80 percent Kabyé. ${ }^{166}$ Given the demographics of Togo, the military feared that free and fair elections would lead to an increase in power by the Ewe ethnic group. ${ }^{167}$ The Kabyé ethnic group comprises 12 percent of the population, while the Ewe ethnic group in the south comprises about 21 percent. ${ }^{168}$ Natachaba is a member of the Chokossi ethnic group. ${ }^{169}$

The unconstitutional seizure of power was swiftly condemned as a military coup d'état by the UN, AU, and ECOWAS. ${ }^{170}$ For example, Secretary-General Annan publicly expressed concern over the extraconstitutional transfer of power in Togo in 2005, commenting that it had "not been done in full respect of the provisions of [Togo's] Constitution." chairman, commented that the seizure of power was unjustifiable. ${ }^{172}$ Alpha Oumar Konare, the Africa Union's West African commissioner, referred to it as a military coup d'état. ${ }^{173}$ The African Union threatened sanctions against Togo unless there was a restoration of "constitutional

\footnotetext{
${ }^{161}$ Ebow Godwin, President's Son Takes Power in West African Coup: New Leader of Togo Named Without Required Elections, CHI. SUN-TIMES, Feb. 7, 2005, at 35. See also The Struggle Continues in Togo, supra note 160.

${ }^{162}$ The Struggle Continues in Togo, supra note 160.

${ }^{163} \mathrm{Id}$.

${ }^{164}$ Dynastic Dictatorship, AFR. ConfidenTIAL, Feb. 2005, at 5.

${ }^{165} \mathrm{Id}$.

${ }^{166} \mathrm{Id}$.

${ }^{167} \mathrm{Id}$.

${ }^{168}$ Presidential Candidates, 42 AFR. RES. BULL. 16,141, 16,142 (Mar. 2005).

${ }^{169}$ Dynastic Dictatorship, supra note 164, at 6.

${ }^{170}$ Clayton, supra note 155. See also Pressure Mounts on Gnassingbe, AFR. ANALYSIS, Feb. 25. 2005, at 1, available at ProQuest (search the Ethnic Newswatch database for "Pressure Mounts Gnassingbe") (showing that ECOWAS and AU called for Faure's resignation and the return of constitutional order).

${ }^{171}$ Annan Calls on Togolese to Respect own Constitution in Appointing Presidential Successor, UN NEws SERvice, Feb. 7, 2005, at 1, available at http://www.un.org/apps/news/ printnewsAr.asp?nid=13261.

${ }^{172}$ Clayton, supra note 155

${ }^{173}$ Id.
} 
legality." 174 Tensions in Togo escalated as protestors took to the streets in opposition to Faure. ${ }^{175}$ ECOWAS placed sanctions on Togo, suspending it from participating in the organization, placed a travel ban on its leaders, and imposed an arms embargo against the country. ${ }^{176}$ After on-and-off negotiations and hard diplomacy by ECOWAS, and massive street protests by thousands of Togolese resulting in violent clashes with police and numerous deaths, ${ }^{177}$ the situation in the country became increasingly tense. A week after the protest-related killings, over one hundred thousand citizens flooded the streets of Lome to challenge Faure's succession. ${ }^{178}$

Simultaneously, the African Union Peace and Security Council (AUPSC) demanded a return to constitutional rule, authorized sanctions against Togo, ${ }^{179}$ and openly supported those sanctions imposed by ECOWAS. ${ }^{180}$ A few days after ECOWAS imposed sanctions, Faure Gnassingbe resigned as interim president of Togo, ${ }^{181}$ causing some discord among the various stakeholders as to whom should succeed Eyadema. ${ }^{182}$ However, political muscle by ECOWAS managed to forge a solution that eventually led to presidential elections. To the dismay of the AU and ECOWAS leadership, Faure Gnassingbe was elected president with approximately 60 percent of the vote. ${ }^{183}$

Actions taken by ECOWAS and the AU to ensure a lawful and constitutional transition of power in Togo succeeded. This was the second time that an acting African president resigned due to internal and external pressure, the resignation of Charles Taylor in Liberia in August 2003 being the first. What makes the case of Togo unique is that a state-

\footnotetext{
174 Nico Colombant, Protest Mount Against Togo's New Leader, VoICE OF AMERICA, Feb. 8, 2005, available at 2005 WLNR 1830699.

${ }^{775}$ Brian Mealer, Three Killed in Togo Coup against Military President, SUNDAY INDEP. (Dublin), Feb. 13, 2005. See also Pressure Mounts on Gnassingbe, supra note 170.

${ }^{176}$ World in Brief, Sanctions Placed on Togo, After 'Coup,' THE OBSERVER (London), Feb. 20, 2005, at News 26.

${ }^{177}$ Pressure Mounts on Gnassingbe, supra note 170.

${ }^{178}$ Id.

179 William Eagle, AU Reiterates Support for West African Efforts to End Togo Crisis, VoICE of AMERICA, Feb. 25, 2005, available at 2005 WLNR 2993380. See also Press Release, AU Condemns 'Military Coup,' Suspends Togo, AU Peace and Security Council (Feb. 25, 2005), available at www.africafocus.org/docs05/togo0502.php.

180 AU Condemns 'Military Coup,' Suspends Togo, supra note 179.

181 Lydia Polgreen, West Africa Wins Again, with a Twist, N.Y. Times, Feb. 27, 2005, at 18.

182 Faure Falters, AFr. CONFIDENTIAL, Mar. 4, 2005, at 5.

${ }^{183}$ Fears of Armed Insurrection, AFR. ANALYSIS, May 6, 2005, at 1, available at ProQuest (search the Ethnic Newswatch database for "Fears Armed Insurrection" and select May 6, 2005 article from the results).
} 
sanctioned and unconstitutional transition of power by a duly elected legislature was peacefully and successfully reversed by a regional organization-albeit domestic protests were critical. Moreover, African leaders themselves levied the central political pressure on Faure Gnassingbe to resign, not Westerners, as was the case in Liberia. This also was the second time that there was clear and unambiguous condemnation of an unconstitutional change in power by the $\mathrm{AU}$, ECOWAS, UN, and wider international community; Sierra Leone was the first. The actions of ECOWAS and the AU in Togo serve as yet another example of their willingness to employ force to protect democracy and the rule of law.

This is the background to the development of ECOWAS law, which has evolved over the past thirteen years to meet the growing security challenges in West Africa. ECOWAS has developed from an organization created to spur regional economic integration and development into a viable regional collective security arrangement. The harsh consequences of warfare on peace, security, democratization, and development in West Africa have forced the organization to establish an innovative collective security system. ECOWAS law not only lays down an unambiguous framework for the protection of democracy, human rights, and the rule of law, it also codifies rights to PDI and humanitarian intervention. The revolutionary evolution of ECOWAS law comes at the behest of West African nations, which have consistently demonstrated their willingness to forfeit sovereignty for peace, security, and democracy. These developments have no doubt influenced the wider corpus of international law, particularly the jus ad bellum, and similarly have been influenced by it.

In the West Africa region, the development of PDI has occurred, not only within the context of regional organizations such as ECOWAS, but also by ad hoc coalitions composed of states from West and Central Africa. The most vivid example is the 1997 Mission for the Implementation of the Bangui Agreement operation in the Central African Republic, which was primarily composed of ECOWAS member states, including Burkina Faso, Côte d'Ivoire, Gabon, Mali, Senegal, and Togo.

\section{The Central African Republic}

On April 18, 1996, the government of President Angel-Felix Patasse (of the Sara group) was destabilized by the first of a series of 
mutinies by segments of the Armed Forces of the Central African Republic (CAR) due namely to "widespread public discontent over social and economic problems exacerbated by prolonged non-payment of salary arrears." 184 Many public servants, including members of the armed forces, had been demanding payment of salary arrears from 1992. ${ }^{185}$ According to Premier Jean-Paul Ngoupande, the mutineers sought to overthrow Patasse's government. ${ }^{186}$ However, the crisis was temporarily halted when Paris unblocked seven hundred million CFA francs, "alongside CFA three hundred million from the CAR Treasury, to meet the arrears." 187

Thereafter, conditions in the country worsened due to severe economic problems precipitated by the 1996 mutinies and acute poverty, which affected 35.5 percent of the population. ${ }^{188}$ As a result, the country underwent successive army mutinies throughout 1996, the last of which was thwarted by robust military intervention by French Legionnaires (primarily of African origin). ${ }^{189}$ The intervention resulted in the deaths of two French soldiers and eventually led to France's withdrawal. ${ }^{190}$ The situation in the country, however, continued to deteriorate, leading to two more military uprisings that further destabilized Patasse's government. ${ }^{191}$

On May 18, 1996, Sergeant Major Isidore Mathurin Dokodo, one of the leaders of the April mutiny, and Lieutenant Zao took over about two-fifths of Bangui, the capital city, for four days. ${ }^{192}$ Both men are of Yakoma origin. ${ }^{193}$ Along with three hundred men from the Regiment Mixte d'Intervention, they took over part of the capital temporarily and garnered a moderate amount of support for the coup from the civilian

\footnotetext{
184 The Secretary-General, Report of the Secretary-General Pursuant to Resolution 1136 (1997) Concerning the Situation in the Central African Republic, I 4, delivered to the Security Council, U.N. DoC. S/1998/61 (Jan. 23, 1998) [hereinafter Report of the Secretary-General Pursuant to Resolution 1136]. See also Angel on a Pinhead, AFR. CONFIDENTIAL, May 10, 1996, at 3; Mutineers' Mistake, 37 AFR. CONFIDENTIAL, June 7, 1996, at 8. One interesting point here is that the mutineers appeared to be more concerned with receiving salary arrears than toppling the government. In fact, it may be argued that the May mutiny was apolitical and corporatist.

185 Angel on a Pinhead, supra note 184, at 3.

${ }^{186}$ Echoes of Zaire, AFr. ConfIDENTIAL, Nov. 29, 1996, at 4.

187 Angel on a Pinhead, supra note 184, at 3.

188 The Secretary-General, Report of the Secretary-General on the United Nations Mission in the Central African Republic, II 30, delivered to the Security Council, U.N. Doc. S/1998/540 (June 19, 1998).

${ }^{189}$ Echoes of Zaire, supra note 186, at 5; Mutineers' Mistake, supra note 184, at 8.

190 French Leave, AFR. CONFIDENTIAL, Oct. 10, 1997, at 7.

191 Levitt, African Interventionist States, supra note 8, at 32.

192 Mutineers' Mistake, supra note 184, at 8. See also Echoes of Zaire, supra note 186, at 4.

${ }^{193}$ Levitt, African Interventionist States, supra note 8, at 32.
} 
populace. ${ }^{194}$ Nevertheless, Patasse's government remained in effective control of the state. France, said to have twenty-five hundred legionnaires in the country, took the lead role in countering the attack. ${ }^{195}$ It decided to launch a retaliatory attack against the rebels for killing several French Legionnaires, not to preserve Patasse's government. ${ }^{196}$ Although no official death toll was released, some in the CAR believed that several hundred civilians died along with thirteen French Legionnaires. ${ }^{197}$ As a result, French action was severely scrutinized in Paris, and amid growing pressure from the French parliament and President Patasse, who held the country's former colonial patron in disdain, France began to withdraw troops from the CAR in late September $1997 .{ }^{198}$

Pursuant to requests by Patasse during the Nineteenth Summit Meeting of Heads of State and Government of France and Africa held in Ouagadougou, Burkina Faso, in December 1996, the presidents of Gabon, Burkina Faso, Chad, and Mali formed an International Mediation Committee (IMC) to help resolve the conflict. ${ }^{199}$ In accordance with the Conference on Consensus-Building and Dialogue, held in Bangui in late January 1997, and in response to requests by Patasse, the member states of the IMC, chaired by President Omar Bongo of Gabon, established an Inter-African Force to Monitor the Implementation of the Bangui Agreements (MISAB) on January $31,1997 .{ }^{200}$ The MISAB was

${ }^{194}$ Echoes of Zaire, supra note 186, at 4 . The mutiny was in part a manifestation of deep-seated ethno-political tensions between followers of ex-President Andre Kolingba, who was from the Yakoma group, and his successor Patasse, who was from the Sourmah-Kaba clan of the Sara (15 percent of the population). The mutiny was triggered when the Presidential Guard (hereinafter Guard) attempted to arrest Captain Anicet Saulet Yavro for financial irregularities. Yavro was a senior representative of the Yakoma group and former head of the Sociéte Centrafricaine de Telecommunications under the Kolingba regime. Yavro attempted to evade arrest and shot and killed a member of the Guard. Thereafter, the same Yakoma troops who orchestrated mutinies earlier that year came to his aid and attacked the Guard and other loyalist forces. To make matters worse, the military did not trust that Patasse would honor or implement a general amnesty to which they were entitled under an earlier peace agreement between the government and military stemming from mutinies in April 1996. They believed that he would arrest their leaders and disband their regiment. Mutineers' Mistake, supra note 184, at 8 . The participants of the May mutiny, led by Sergeant Major Isidore Mathurin Dokodo, were the same group that mutinied earlier that year.

${ }^{195}$ Mutineers' Mistake, supra note 184, at 8. This represented the fourth time that French troops have intervened to save Patasse's regime. French Leave, supra note 190, at 7.

${ }^{196}$ Mutineers' Mistake, supra note 184 , at 8.

${ }^{197}$ Echoes of Zaire, supra note 186, at 4.

198 Levitt, African Interventionist States, supra note 8, at 32.

199 Id. at 33.

${ }^{200}$ Letter dated 4 July 1997 from Mr. Ange-Félix Patasse, President of the Central African Republic, addressed to the Secretary-General, reprinted in Security Council, Identical Letters 
mandated to restore peace and security to the country and monitor the implementation of the Bangui peace agreements. ${ }^{201}$ In this regard, it was sanctioned to conduct operations to disarm the former rebels, the militia, and all other unlawfully armed persons, and maintain peace and security. ${ }^{202}$

To support MISAB's efforts, on August 6, 1997, the UN Security Council adopted Resolution 1125 , which deemed the situation in the CAR a threat to international peace and security and authorized the MISAB to take enforcement action to ensure the security and freedom of movement of its personnel. ${ }^{203}$ The UN Security Council adopted additional resolutions in this connection. For example, on March 27, 1998, it adopted Resolution 1159 creating the UN Mission in the CAR (MINURCA) to assist in the maintenance of peace, security, law, and order; ensure security and freedom of movement of UN personnel and the safety and security of UN property; and provide police training for the national police and technical support to national electoral bodies. ${ }^{204}$ The UNSC mandated Secretary-General Annan to "secure a smooth transition between MISAB and MINURCA by 15 April 1998." 205

While there were several legal bases for the intervention, ${ }^{206}$ what is unique about the MISAB operation is that it marked the first time that an ad hoc group of states in Africa collectively deployed forces in a state outside of their region to prevent civil war by safeguarding a fledging DCG. ${ }^{207}$

The interventions by ECOWAS in Liberia, Sierra Leone, GuineaBissau, Côte d'Ivoire, and Togo, the institution of new conflict mechanisms, and the MISAB operation in the CAR were all premised in part on the notion that the threat or overthrow of a DCG was a root cause of underdevelopment and insecurity in West Africa and Africa generally.

Dated 18 July 1997 From the Chargé D'Affaires A.I. of the Permanent Mission of the Central African Republic to the United Nations Addressed to the Secretary-General and to the President of the Security Council, U.N. Doc. S/1997/561 (July 22, 1997).

201 Mandate of the Inter-African Force to Monitor the Implementation of the Bangui Agreements, art. 2, reprinted in Security Council, supra note 200.

${ }^{202} \mathrm{Id}$.

${ }^{203}$ Id. 9 . 9.

${ }^{204}$ S.C. Res. 1159, भII 9-10, U.N. Doc. S/RES/1159 (Mar. 27, 1998). Approximately 1,350 personnel partook in the mission.

205 Id. 111.

${ }^{206}$ For an analysis of the legal bases for the MISAB intervention in the CAR, see Levitt, African Interventionist States, supra note 8, at 31-35.

${ }^{207}$ It is important to note that the MISAB mission in the CAR was, with the exception of Chad, composed entirely of West African states. $I d$. at 35 . 
These threats or coups therefore were prohibited in law and protected against in practice.

As the next section will illustrate, like ECOWAS and certain states in Central Africa, the South African region has also taken assertive action to fashion new security structures and employ force to safeguard democracy.

\section{The Southern African Development Community}

ECOWAS has fashioned the most radical law and collective security framework on intervention, but it is not alone in its efforts. The Southern African Development Community (SADC) has also established a new regime and dynamic framework to ensure peace, security, and democracy in southern Africa.

\section{A. THE SADC TREATY AND ORGAN}

The SADC emerged in January 1992 as the successor organization to the Southern African Development Co-ordination Conference, which had been founded by the then front-line states in order to reduce regional dependence on apartheid South Africa. ${ }^{208}$ The succession appears to have been partly inspired by the changing political environment in South Africa following Nelson Mandela's release from prison in 1990 and the ongoing efforts to fully dismantle the country's apartheid system. ${ }^{209}$ In October 1993 the new SADC Treaty entered into force. ${ }^{210}$ It is concerned with involving the people in the southern Africa region in the process of development, particularly through the "guarantee of democratic rights, observance of human rights and the rule of law."211 In fact, one of its core principles is that SADC and its member states respect and protect "human rights, democracy, and the rule of law." 212 In this context, two of the SADC's

${ }^{208}$ Levitt, The Law on Intervention, supra note 1, at 55. See also Angola-Botswana-LesothoMalawi-Mozambique-Namibia-Swaziland-Tanzania-Zambia-Zimbabwe: Treaty of the Southern African Development Community, August 17, 1992, 32 I.L.M. 116 [hereinafter SADC Treaty].

209 Levitt, The Law on Intervention, supra note 1, at 55.

${ }^{210}$ SADC Treaty, supra note 208 , at 116.

211 Id. at pmbl.

${ }^{212}$ Id. art. 4(c). 
key objectives are to "evolve common political values" and "promote and defend peace and security." 113

In an effort to build capacity and systematize its approach to conflict management and security, the SADC adopted an important security instrument.

\section{B. THE SADC ORGAN}

In June 1996 SADC adopted the Organ on Politics, Defense and Security (OPDS). ${ }^{214}$ Like the SADC Treaty, one of its key principles is the observance of "human rights, democracy and rule of law." 215 While the OPDS has numerous objectives, protecting the people and the development of the region from instability from the "breakdown of law and order," including all types of conflict, and the promotion of democratic institutions and practices are central. ${ }^{216}$ Objective (g) states that where diplomatic efforts fail, the OPDS is responsible for recommending punitive measures to the summit of the heads of state of SADC members. ${ }^{217}$ It also states that measures to be taken in this regard will be further elaborated in a protocol on peace, security, and conflict resolution. ${ }^{218}$

The SADC system was tested in 1998 when the government of the small landlocked nation of Lesotho was challenged from within.

\section{Lesotho}

The root causes of the Lesotho crisis in 1998 can be traced back to events in 1993 when the Lesotho Congress for Democracy (LCD) was elected into power. ${ }^{219}$ Political party rivalry stemming from the adoption of the Constitution of Lesotho, which entered into force on April 2 of that year, was severe, and structural tensions between elements of the

\footnotetext{
${ }^{213} I d$. arts. 5 (b), (c).

${ }^{214}$ Communique from the 1996 Extra-Ordinary SADC Summit to Launch the SADC Organ (1996), http://www.sadc.int/news/news_details.php?news_id=215 [hereinafter SADC 1996 Communiqué]. See also AfriCA: SEleCted Documents, supra note 60, at 327; Willie Breytenbach, Failure of Security Co-operation in SADC: The Suspension of the Organ for Politics, Defence and Security, 7 S. AFr. J. OF INT'L AFF., 85, 86 (2000); Levitt, The Law on Intervention, supra note 1, at 55.

${ }^{215}$ SADC 1996 Communiqué, supra note 214.

${ }^{216} \mathrm{Id}$.

217 Levitt, The Law on Intervention, supra note 1, at 55.

${ }^{218}$ Id.

${ }^{219}$ Levitt, African Interventionist States, supra note 8, at 35.
} 
security forces and the executive in 1994 also combined to ignite the 1998 crisis. ${ }^{220}$ From 1997 onward, political tensions escalated as political rifts continued unabated between LCD on one hand and the Basotho National Party (BNP), Basotholand Congress Party (BCP), and the Maramatlou Freedom Party (MFP) on the other. ${ }^{221}$ In early September 1998 such tensions found overt political expression when approximately ten thousand opposition protestors camped outside the palace of King Letsie III. ${ }^{222}$ Their protests arose amid allegations from opposition party leaders that the LCD rigged the May 1998 elections in which it won seventy-nine of Lesotho's eighty voting districts. ${ }^{223}$ The situation was further exacerbated by the delayed release of the findings of the Troika Commission (consisting of Botswana, South Africa, and Zimbabwe) with regard to the elections ${ }^{224}$ and by Prime Minister Phakalitha Mosisili's dismissal of a well-respected military officer for sympathizing with election demonstrators. ${ }^{225}$ Taken together, these factors exacerbated political discontent among segments of the civilian populace and numerous junior military officers, creating an extremely volatile environment. ${ }^{226}$

On September 11, 1998, these officers began a mutiny, arguably orchestrated by Finance Minister Retselisistoe Sekonyana's BNP, against the government. ${ }^{227}$ They arrested twenty senior military officials and forced their commander, Lieutenant General Makhula Mosakeng, to broadcast his resignation over Radio Lesotho. ${ }^{228}$ Consequently, several violent clashes broke out between loyalist and opposition forces. ${ }^{229}$ When Mosisili returned from a SADC meeting in Mauritius on September 15, he found the country in turmoil. Mutinous soldiers and other protesters stole and impounded eighty government vehicles from civil servants and stoned vehicles belonging to ministers, looted local homes and businesses, burned down government buildings, prevented

\footnotetext{
${ }^{220} \mathrm{Id}$.

${ }^{221}$ Id. at 36.

$222 \mathrm{Id}$.

${ }^{223}$ Id.

${ }^{224}$ The Troika Commission (or Langa Commission) was established by the parties at conflict to investigate allegations of foul play by Lesotho's Independent Electoral Commission and was presided over by Pius Langa, the deputy president of South Africa's Constitutional Court. Militants and Monarchs, AFr. CONFIDENTIAL, Sept. 25, 1998, at 6.

${ }^{225}$ Id. at 6 (text box titled "Military Mayhem").

${ }^{226}$ Levitt, African Interventionist States, supra note 8, at 36.

${ }^{227}$ Id.

${ }^{228}$ Militants and Monarchs, supra note 224, at 5.

${ }^{229}$ Id.
} 
government employees from going to work, and made death threats against Mosisili and other senior officials. ${ }^{230}$ In addition, on September 18, opposition parties demanded the "government's resignation, the dissolution of parliament and the appointment by the King of an interim government including equal numbers from all major parties." ${ }^{231}$ The capital city, Maseru, was in chaos as elements in the Lesotho military and police force, which appeared to sympathize with the protestors, took no action to quell the mutiny. ${ }^{232}$

Fearing that a military coup d'état was imminent and uncertain about how long loyalist forces could maintain law and order, Prime Minister Mosisili requested that South Africa, Botswana, Zimbabwe, and Mozambique militarily intervene to restore law and order to Lesotho in "accordance with SADC agreements." ${ }^{233}$ Nevertheless, his government remained in effective control of the state. ${ }^{234}$ On September 22, after Zimbabwean Robert Mugabe, president and former chairman of the OPDS, ${ }^{235}$ allegedly refused to receive communications from Buthelezi about the Lesotho crisis, South Africa sent six hundred troops and Botswana sent two hundred troops to Lesotho pursuant to Mosisili's request. ${ }^{236}$ South African forces launched a robust intervention early that morning, which resulted in the deaths of 49 soldiers on both sides and the

${ }^{230}$ SA Troop Alert as Meseru Mutinies, MAIL \& GUARDIAN OnLINE (Johannesburg), Sept. 24, 1998, http://www.mg.co.za/articledirect.aspx?articleid=181249\&area=\%2farchives_print_edition\%2f; Mayhem Spreads Throughout Lesotho, MAIL \& GuARDIAN ONLINE (Johannesburg), Sept. 24, 1998, http://www.mg.co.za/articledirect.aspx?articleid $=214086 \&$ area $=\% 2$ farchives_online edition\% $2 \mathrm{f}$.

${ }^{231}$ Levitt, African Interventionist States, supra note 8, at 36.

232 Id.

${ }^{233}$ Id. It is doubtful that SADC could validly invoke a right of humanitarian intervention. At the time of the intervention, there were no widespread violations of human rights that amounted to grand human suffering: the government had not collapsed, nor was it descending into anarchy. Although it is debatable whether the LCD government was in the process of being violently and illegally dislodged, the people of Lesotho were arguably ambivalent about the mutiny or attempted coup. Consequently, South Africa and Botswana were entitled to rely on SADC law and Mosisili's request as bases for intervening.

${ }^{234}$ Levitt, African Interventionist States, supra note 8, at 37.

${ }^{235}$ SADC 1996 Communiqué, supra note 214. See generally SADC, Strategic Indicative Plan for the Organ on Politics, Defense and Security Cooperation, Aug. 5, 2004 [hereinafter SADC Plan for the Organ for Politics, Defense \& Security], available at http://www.sadc.inv/ english/documents/legal/protocols/politics.php\#2; Breytenbach, supra note 214, at 85; Maxi van Aardt, The SADC Organ for Politics, Defence and Security: Challenges for Regional Community Building, S. AFr. J. OF INT'L AFF., Winter 1997, at 144.

${ }^{236}$ South Africa and Botswana later increased these numbers to 1000 and 460 , respectively. To a Little Kingdom, AFr. CONFIDENTIAL, Oct. 9, 1998, at 6-7. 
capture of 170 mutinous Lesotho soldiers. ${ }^{237}$ Botswana contingents arrived later in the day. ${ }^{238}$ Arrival of reinforcements from South African and Botswana exacerbated the crisis; ${ }^{239}$ nevertheless, by the end of October 1998 Maseru began to return to normal, and the LCD and opposition parties signed a tentative peace agreement. ${ }^{240}$

\section{South Africa and Botwana's SADC Intervention}

The South African and Botswanan intervention in Lesotho can legally be justified as a SADC operation because it took place under the "authoritative veil" of SADC, among other reasons; ${ }^{241}$ however, from an operational standpoint, it clearly was not coordinated by the SADC secretariat or other authority in the organization. It was, rather, an ad hoc operation conducted by South Africa and Botswana in accordance with or under SADC law. ${ }^{242}$ This point explains why some analysts have, perhaps rightly, scrutinized the political and operational problems associated with the status and function of the OPDS vis-à-vis the Lesotho crisis. $^{243}$ Hence, a distinction must be drawn between legal and operational concerns related to the mission, as the legal framework for the OPDS had already been adopted at the time of the intervention, and thus it forms an important part of the jus ad bellum in the southern African region. ${ }^{244}$

Like Doe, Kabbah, Vieira, and Patasse, Mosisili requested outside assistance to restore law and order and preserve his government. What makes the Lesotho intervention unique is that it was the first

${ }^{237}$ Verbatim Mall \& GUARDIAN ONLINE (Johannesburg), Sept. 25, 1998, http://www.mg.co.za/ articledirect.aspx ?articleid $=208438$ \&area $=\% 2$ farchives_print_edition $\% 2 \mathrm{f}$ (quoting Nelson Mandela).

${ }^{238}$ Levitt, African Interventionist States, supra note 8, at 37.

239 Id.

${ }^{240} \mathrm{Id}$.

${ }^{241}$ Id. at $35-40$.

${ }^{242}$ Id. at 40. South Africa and Botswana's intervention in Lesotho was similar to Nigeria's in Liberia (1990) and Senegal and Guinea's into Guinea-Bissau (1998) except that the Lesotho operation was not followed by a formal SADC or UN operation as was the case in the aforementioned examples.

${ }^{243}$ Id. One key reason why the OPDS was dysfunctional was because of geopolitical tensions between Mandela and Mugabe. For example, Mandela wanted it to be under the political and jurisdictional control of the Summit of the Heads of State and Government of SADC whereas President Mugabe insisted that it be autonomous.

${ }^{244}$ For purposes of this analysis, whether South Africa and Botswana followed internal SADC procedures before deploying forces does not appear to affect the legality of the operation in the broad sense or invalidate it from being a hard example of PDI. 
intervention by a regional organization to safeguard a DCG in the southern Africa region and serves as yet another example of the readiness of African regional organizations to use force to protect democracy or legitimate rule.

In the wake of the Lesotho operation, SADC made concerted efforts to strengthen the legal and operational bases for future peace and security operations and eventually adopted a protocol on politics, defense, and security cooperation.

\section{THE SADC CONFLICT PROTOCOL}

The SADC Protocol on Politics, Defense and Security Cooperation formally came into force on March 2, 2004 . It aims to strengthen the OPDS by supporting cooperation in regional security through conflict management and coordination of member states in international and regional peacekeeping, including enforcement measures. ${ }^{245}$ Furthermore, as with Paragraph 46 of the ECOWAS framework, Article 11(2)(b) of the SADC Protocol sets out elaborate criteria for when the OPDS may authorize regional intervention in internal conflicts. These criteria include when there is (1) large-scale conflict or violence between sections of the population of a state or between the state and/or its armed or paramilitary forces and sections of the population; (2) a threat to the legitimate authority of the government (such as a military coup); (3) a condition of civil war or insurgency; and (4) any crisis that could threaten the peace and security of other member states. ${ }^{246}$ Under the protocol, the OPDS may also decide to intervene in a state when a conflict "threatens peace and security in the region." $" 247$

Hence, the laws of SADC codify not only a right to PDI but also the right of the community to quell nearly every conceivable type of threat to legitimate authority and safeguard legitimate regimes irrespective of their political character. The development of ECOWAS and SADC rules on the preservation of DCGs coincided well with the emergence of the African Union and its new framework for protecting against unconstitutional changes of government.

${ }^{245}$ SADC, Protocol on Politics, Defense and Security Co-operation, art. 2(f)(k), Aug. 14, 2001, available at http://www.sadc.int/english/documents/legal/protocols/politics.php\#2.

${ }^{246}$ Id. art. 11(2)(b) (emphasis added).

${ }^{247}$ Id. art. 11 (2)(a)(iii). 


\section{THE AFRICAN UNION}

The Constitutive Act of the African Union came into force in March 2001. ${ }^{248}$ The Act lays out a completely new security and governance framework for the African continent. The African Union's new European Union-like structure varies considerably from that of its predecessor, the Organization of African Unity.

Article 4, on the principles of the African Union, includes three very important provisions on regional security, peacekeeping, and democracy: One accords the union the "right" to intervene in a member state in respect of "grave circumstances," namely, war crimes, genocide, and crimes against humanity; ${ }^{249}$ another accords member states the "right" to request the AU to intervene in order to restore peace and security; ${ }^{250}$ and the third provision condemns and rejects unconstitutional changes of government. ${ }^{251}$ These provisions complement and "continentalize" those enumerated in ECOWAS and in SADC law.

Nearly two years after the adoption of the Constitutive Act the AU expanded its authority to employ force in AU member states with the adoption of the Protocol on Amendments to the Constitutive Act of the African Union. ${ }^{252}$ Specifically, the protocol expanded the scope of Article 4(h) to not only empower the AU with the power to intervene in member states to prevent war crimes, genocide, and crimes against humanity but also when there is a "serious threat to legitimate order", which goes beyond the horatory and toothless "right" of condemnation and rejection provided for in the Constitutive Act. ${ }^{253}$ It also modifies and expands the powers enumerated in the AUPSC Protocol from merely imposing sanctions in response to unconstitutional changes of

\footnotetext{
${ }^{248}$ The Constitutive Act of the African Union, art. 4(h), July 11, 2000, available at http://www.africa-union.org/root/au/AboutAU/Constitutive_Act_en.htm, reprinted in AFRICA: SELECTED DOCUMENTS, supra note 60 , at 35,41 .

${ }^{249} I d$, reprinted in AFRICA: SELECTED DOCUMENTS, supra note 60 , at $35,41$.

${ }^{250}$ Id. at 4(g), reprinted in AFRICA: SELECTED DOCUMENTS, supra note 60, at 35, 41.

${ }^{251}$ Id. at 4(p), reprinted in AFRICA: SELECTED DOCUMENTS, supra note 60, at 35, 41.

${ }^{252}$ African Union, Protocol on Amendments to the Constitutive Act of the African Union (2003), available at http://www.africa-union.org/root/au/Documents/Treaties/treaties.htm (follow "Protocol on Amendments to the Constitutive Act of the African Union" hyperlink) [hereinafter African Union, Amendments to the Constitutive Act Protocol] (adopted by the 1st Extraordinary Session of the Assembly of the Union in Addis Ababa, Ethiopia, on Feb. 3, 2003 and by the 2d Ordinary Session of the Assembly of the Union in Maputo, Mozambique, on July 11, 2003). The Protocol came into force on July 25, 2006.

${ }^{253}$ Id. at art. 4(p).
} 
government to the use of force to reverse them. The AU's expansion of the right to use force to safeguard legitimate order essentially codifies a right to PDI in AU law and serves as yet another example of the crystallization of a norm of PDI in Africa.

\section{A. THE NEW PARTNERSHIP FOR AFRICA's DEVELOPMENT}

The AU's new approach to safeguarding democracy was further elaborated in the New Partnership for Africa's Development (NEPAD), which is a framework of interaction and program of action established by African leaders to renew the continent through a series of initiatives in conflict mitigation, democracy and governance, human rights and the rule of law and security, among others. ${ }^{254}$

The Peace and Security and Democracy and Political Governance initiatives of NEPAD acknowledge that development is impossible in the "absence of true democracy, respect for human rights, peace and good governance." 255 Under NEPAD, African states agreed to "respect the global standards of democracy," allowing for fair democratic elections to "enable people to choose their leaders freely" and achieve "basic standards of good governance and democratic behavior."256

The crises in São Tomé and Príncipe would serve as the AU's first real test of its commitment to democracy.

\section{B. SÃo TOMÉ AND PRÍNCIPE}

On July 15, 2003, while he was attending an African/AfricanAmerican summit in Nigeria, ${ }^{257}$ President Fradique de Menezes of São Tomé and Príncipe was dislodged in a bloodless coup d'état by a small group of junior military officials, led by Major Fernando Pereira. ${ }^{258}$ The coup leaders captured Prime Minister Maria das Neves, Natural Resources Minister Rafael Branco, Defense Minister Fernando Danqua, and Finance Minister Maria Tebús Torres. ${ }^{259}$ The government officials

\footnotetext{
${ }^{254}$ New Partnership for African Development, $\mathbb{T H}$ 47-49, October 2001, http://www.nepad.org/ 2005/files/documents/inbrief.pdf.

${ }^{255}$ Id. $\mathbb{1} 79$.

${ }^{256}$ Id. See also id. II 82.

${ }^{257}$ Kudos for Obasanjo's Bullying Diplomacy, AFR. ANALYsis, Aug. 8, 2003, at 3, available at ProQuest (search the Ethnic Newswatch database for "Obasanjo Bullying Diplomacy").

${ }^{258}$ Coup in Island State with Big Oil Reserves, UN INTEGRATED REGIONAL INFO. NETWORKS, July 16, 2003, available at 2003 WLNR 343477.

${ }^{259}$ Desperados, AFr. CONFDENTIAL, July 25, 2003, at 8.
} 
were released shortly after their capture after pressure from international mediators coordinated by Congo-Brazzaville's foreign minister, Rodolphe Adada. ${ }^{260}$

The coup included elements that attempted to seize power in 1988 along with former soldiers from apartheid South Africa's infamous 32nd Buffalo Battalion. ${ }^{261}$ The coup seems to have been precipitated by various internal and external actors vying for political power and interests in the country's oil reserves. ${ }^{262}$ However, coup leaders stated that they chose to take action in response to the country's poor standard of living and chronic political instability. ${ }^{263}$ There has been some speculation that disgruntled members of the Christian Democratic Front (FDC) helped organize the coup, given allegations of corruption in the

${ }^{260} \mathrm{Id}$.

261 Troubled Waters Over Oil: Oil Curses Another African State, THE ECONOMIST, July 19, 2003, at 37. See also Sao Tome and Principe: Mercenaries, Corruption and Poverty Complicate the Road to an Oil Boom, U.N. OFFICE FOR THE COORD. OF HuMANIT'N AFFAIRS, Sept. 9, 2006, http://www.irinnews.org/print.asp?ReportID=47129; Gerhard Seibert, Coup d'état in São Tomé $e$ Príncipe: Domestic Causes, the Role of Oil and Former "Buffalo" Battalion Soldiers 4, Inst. For Security Stud., paper 81 (Nov. 2003), available at http:/www.iss.co.za/pubs/papers/ 81/paper81.pdf; Johann Smith, Inst. for Security Stud., Memorandum on S. Tomé e Principe 5, n.1 (July 17, 2003), available at http:/www.iss.co.za/AF/current/saotomejul03.pdf. The FDC was founded in the late 1990 s by former members of the National Resistance Front of São Tomé and Príncipe (FRNSTP). The group was in opposition to the socialist policies of São Tomé president Manuel Pinto da Costa and was exiled to Liberville, Gabon. President Omar Bongo of Gabon supported the group because he wanted to prevent São Tomé and Príncipe from being integrated into the alliance of Algiers, Conakry, Brazzaville, and Luanda. Once São Tomé and Príncipe began to liberalize, Bongo reconciled with the ruling party and expelled the FRNSTP. The group sought refuge in Kribi, Cameroon, in 1986. After cleavages emerged in the group, most members of the FRNSTP left Cameroon and sought asylum in the South African-controlled area of Walvis Bay in Nambia. The majority of those relocated to Nambia were descendants of Cape Verdian contract workers. They were detained as illegal immigrants by South Africa and forced to either fight with the 32d Buffalo Battalion or remain in prison. Fifty-three members of the FRNSTP fought for the apartheid regime of South Africa and gained South African citizenship. The 32d Buffalo Battalion was based in northern Nambia and was used as special forces for operations inside of Angola. After Nambia achieved independence in 1990, many of the soldiers began to work for the South African security/mercenary company Executive Outcomes. The remaining members of the FRNSTP who remained in Gabon led an invasion of forty-four mostly unarmed men to overthrow São Tomé's president in 1988. São Tomé security forces quickly detained the group, which had traveled to the country by canoe. Most of the conspirators were tried by a local court in 1989. However, President da Costa pardoned all of them in April 1990. Later that year the FRNSTP members, including 2003 coup leader Sabino dos Santos, formed the FDC. After Executive Outcomes was disbanded in 1998, former FRNSTP members, including the co-leader of the 2003 coup, Alèrcio Costa, joined their old comrades in the FDC.

262 Michael Peel, Middle East and Africa: Leader of Sao Tome Coup Calls for Fresh Elections, FIN. Times (London), July 18, 2003, at 6.

${ }^{263}$ Gethin Chamberlain, Sao Tome Coup Linked to Oil Reserves, Scotsman (Edinburgh), July 17 , 2003 , at 12 . 
way Menezes awarded oil contracts for reserves located in a zone that is being jointly developed with Nigeria. ${ }^{264}$ The waters separating Nigeria and São Tomé and Príncipe contain an estimated six billion barrels of oil. ${ }^{205}$

In particular, the International Monetary Fund determined that deals with Exxon Mobil and Nigeria-based Chrome were unfair. ${ }^{266}$ The president's attempts to renegotiate the contracts led to his public admonishment by senior members of the political class. ${ }^{267}$ In January 2003 the president dissolved parliament, partly because of disagreements over the right of the executive to negotiate oil deals. ${ }^{268}$ Soon after, the parliament was reinstated, but tensions remained over a payment the president received from an oil firm and allegedly used for campaign purposes. ${ }^{269}$ In addition, in October 2002 Menezes dismissed Gabriel Costa as prime minister and replaced him with Maria das Neves. ${ }^{270}$ The president made the change following complaints from the army that Costa improperly promoted two high-ranking officers. ${ }^{271}$ The new prime minister appointed fourteen new government ministers. ${ }^{272}$

The coup was short-lived because of opposition to it by Nigeria, the $\mathrm{AU}$, and other stakeholders. ${ }^{273}$ On the day of the coup, Menezes appealed to the international community and specifically to the governments of Angola and Nigeria to restore him to power. ${ }^{274}$ The coup met with a "storm of international protest ... as neighboring countries, the Africa Union, as well as the United States and the United Nations strongly condemned the one day-old coup. The common position has

${ }^{264}$ Sao Tomé and Principe: Mercenaries, Corruption and Poverty Complicate the Road to an Oil Boom, supra note 261 , at 3.

${ }^{265}$ Peel, supra note 262, at 2.

${ }^{266}$ Troubled Waters Over Oil: Oil Curses Another African State, supra note 261. See also Daphne Eviatar, Sao Tome Residents Hope For Oil Riches Corruption Fears Temper Hopes, BosTON GLOBE, Nov. 30, 2003, at A8 (explaining that, in 1997, a small Houston-based oil company, Environmental Remediation Holding Corp. (ERHC) guaranteed $\$ 5$ million for drilling rights in São Tomé. When Menezes was elected in 2001, he renegotiated the unfair contract after Exxon Mobil was brought in by ERHC. However, it was later revealed that Menezes received $\$ 100,000$ from the chairman of ERHC. Menezes said the money was a campaign contribution.).

${ }^{267}$ Troubled Waters Over Oil: Oil Curses Another African State, supra note 261.

${ }^{268}$ Chamberlain, supra note 263 , at 2.

${ }^{269} I d$.

${ }^{270}$ New Cabinet: Maria das Neves is the Archipelago's First Woman Prime Minister, 39 Afr. ReS. BULL. 15,036 (2002).

271 Id.

${ }^{272}$ Id.

${ }^{273}$ Seven-day Junta: Announced as an "International SOS," Oil Interests and the Chances of Future Gain are Likely to Have Been the Underlying Motive, 40 AFR. RES. BULL. 15,385 (2003).

${ }^{274}$ Smith, supra note 261, at 2-3. See also Seibert, supra note 261, at 5. 
been that the events in STP [São Tomé and Príncipe] amount to an unconstitutional change of government and that STP's constitutional legality must be restored as soon as possible." 275 The Nigerian government condemned the coup as "a gross violation" of the African Union Constitution. ${ }^{276}$ President Joaquim Chissano of Mozambique, former chairman of the $\mathrm{AU}$, likewise condemned the $\operatorname{coup}^{277}$ and stated that the "sole purpose of any negotiation was to restore constitutional order to São Tomé."278 Secretary-General Annan also condemned the coup and called for the "unconditional restoration of constitutional order."279

International pressure and hard diplomacy by Angola, Nigeria, the Economic Community of Central African States, the Community of Portuguese-Speaking Countries, the United States, and Portugal provided little wiggle room for the junta. ${ }^{280}$ President Obasanjo's stern diplomacy produced a peace accord and led to the restoration of Menezes to power ${ }^{281}$ The UN praised the restoration of constitutional order; Annan stated that the "positive outcome of the crisis in Sao Tome and Principe reflects not only the will of African States to work together towards the settlement of crises affecting countries on the continent, but also their determination to promote and safeguard democracy."282

The coup in São Tomé and Príncipe provided the first test for the AU's new peace and security framework. While no intervention was necessary, the AU's use of coercive diplomacy to enforce its rules on unconstitutional changes of government amounted to PDI. It demonstrated that African states are no longer willing to accept as fait accompli unconstitutional seizures of power and that, at the very least in

\footnotetext{
${ }^{275}$ Smith, supra note 261 , at 2.

${ }^{276}$ Chamberlain, supra note 263.

${ }^{277}$ Coup in Island State with Big Oil Reserves, supra note 258.

${ }^{278}$ No Military Intervention Yet, AGENCIA DE INFORMACAO DE MOCABIQUE, July 21, 2003, available at 2003 WLNR 478118.

${ }^{279}$ Press Release, Secretary-General, Secretary-General 'Strongly Condemns' Coup D'Etat in Sao Tome and Principe, U.N. Doc. SG/SM/8781 AFR/666 (July 16, 2003).

${ }^{280}$ Seibert, supra note 261 , at 6 . See also Seven-day Junta, supra note 273 , at $15,385-86$.

${ }^{281}$ Kudos for Obasanjo's Bullying Diplomacy, supra note 257.

${ }^{282}$ Press Release, Secretary-General, Secretary-General Welcomes Restoration of Constitutional Order, Commends Mediation Efforts, in Sao Tome and Principe, U.N. Doc. SG/SM/8791 AFR/676 (July 25, 2003).
} 
Africa, there has been a normative legal shift in the jus ad bellum toward the recognition of democracy as an enforceable right. ${ }^{283}$

In 2003, building on its conflict mitigation experiences and in the wake of its involvement in resolving the conflict in São Tomé and Príncipe, the African Union adopted a peace and security protocol to evolve further its peacemaking and collective security capability.

\section{The AU PEACE AND SECURITY Protocol}

The protocol establishing the Peace and Security Council of the African Union (AUPSC) came into force on December 26, 2003, and serves as the first continent-wide regional collective security system. ${ }^{284}$ The AUPSC is empowered to carry out several important functions that complement and evolve Africa's collective security mechanisms. ${ }^{285}$ Its key function is to promote peace, security, and stability in Africa through early warning, preventive diplomacy, mediation, and, most importantly, peace support operations, intervention, humanitarian action, disaster management, peace-building, post-conflict reconstruction, and any other function as may be decided on by the African Union. ${ }^{286}$ The AUPSC may authorize the use of force in multiple contexts, including to safeguard democracy, thwart conflict or protect human rights, ensure access to humanitarian agencies, and deliver humanitarian relief during natural disasters. ${ }^{287}$

The AUPSC protocol empowers the AU to engage in numerous activities, from policy oversight to full-fledged military intervention. ${ }^{288}$ Furthermore, the AUPSC is charged with instituting

${ }^{283}$ As discussed in preceding sections, the AU's commitment to democracy and the rule of law would be tested two years later in Togo. See generally supra notes 155-83 and accompanying text.

284 African Union, Protocol Relating to the Establishment of the Peace and Security Council of the African Union (July 9, 2002), available at http://www.africa-union.org/root/au/organs/ psc/Protocol_peace\%20and\%20security.pdf [hereinafter African Union, Peace and Security Council Protocol], reprinted in AFRICA: SELECTED DOCUMENTS, supra note 60, at 163. See also Jeremy I. Levitt, The Peace and Security Council of the African Union and the United Nations Security Council: The Case of Darfur, Sudan, in THE SECURITY COUNCIL AND THE USE OF FORCE 213-51 (Niels Blokker \& Nico Schrijver eds., 2005); Jeremy I. Levitt, The Peace and Security Council of the African Union: The Known Unknowns, 13 TRANSNAT'L L. \& CONTEMP. PROBS. 109, 118 (2003).

${ }^{285}$ See generally Levitt, The Peace and Security Council of the African Union, supra note 284.

${ }^{286}$ African Union, Peace and Security Council Protocol, supra note 284, art. 6, TIII (a)-(f), reprinted in AFRICA: SELECTED DOCUMENTS, supra note 60, at 163, 168.

${ }^{287}$ Id. art. 7, Tf $1(\mathrm{a})-(\mathrm{m})$, reprinted in AFRICA: SELECTED DOCUMENTS, supra note 60, at 163, 169.

${ }^{288}$ Id., reprinted in AFRICA: SELECTED DOCUMENTS, supra note 60, at 163, 169. 
"sanctions whenever an unconstitutional change of Government takes place," 289 employing force to protect against a serious threat to legitimate order, ${ }^{290}$ implementing "common defense policy," 291 and co-coordinating and cooperating with subregional and regional mechanisms (and the United Nations), particularly on peace and security issues. ${ }^{292}$ AU member states are bound by AUPSC decisions and actions and "shall extend full cooperation to, and facilitate action by, the Peace and Security Council for the prevention, management and resolution of crises and conflicts." ${ }^{293}$

The AUPSC protocol confers on the AU more explicit legal authority to engage in peace enforcement than the UN Charter does the Security Council. The AU Constitutive Act and AUPSC Protocol clearly delineate the circumstances under which PDI may take place: when regimes come to power extraconstitutionally, to protect against a serious threat to legitimate order, ${ }^{294}$ and during any other breakdown of law and order as determined by the organization. Against this background, it is more than evident that the AUPSC framework was a response to Africa's fragile security environment and reflects African leaders' recognition that an apparatus was needed to deal with any and all security issues, especially serious threats to legitimate order and illegal seizures of power. ${ }^{295}$

${ }^{289}$ Id. art. 7, II I(g), reprinted in AFRICA: SELECTED DOCUMENTS, supra note 60, at 163, 169.

290 African Union, Amendments to the Constitutive Act Protocol, supra note 252, art. 4(h).

291 African Union, Peace and Security Council Protocol, supra note 284, art. 7, II 1(h), reprinted in AFRICA: SELECTED DOCUMENTS, supra note 60, at 163, 169.

${ }^{292}$ Id. art 7, II 1(i), reprinted in AFRICA: SELECTED DOCUMENTS, supra note 60, at 163, 169.

${ }^{293}$ Id. art 7, $\mathbb{1}$ 4, reprinted in AFRICA: SELECTED DOCUMENTS, supra note 60, at 163, 170.

${ }^{294}$ It appears that the expansion of Article 4(h) under the protocol amending the AU Constitutive Act to protect against a serious threat to legitimate authority lowers the threshold for intervention from instances where constitutionally valid regimes have been overthrown to cases where there are grave threats against them. African Union, Amendments to the Constitutive Act Protocol, supra note 252, art. 4(h).

${ }^{295}$ The AU's PDI regime has become even stronger with the emergence of the Draft African Charter on Democracy, Elections and Governance, which not only confirms that democracy is a basic and enforceable right, but also permits intervention when "illegal means of accessing power constitute an unconstitutional change of government" such as a "military coup d'etat against a democratically elected government"; "intervention by mercenaries to replace a democratically elected government"; "replacement of democratically elected government by armed dissidents and rebels"; "refusal of an incumbent government to relinquish power to the winning party after free, fair and regular elections"; and/or "manipulation of constitutions and legal instrument for prolongation of tenure of office by a incumbent regime". Draft African Charter on Democracy, Elections and Governance, Art. 27 (2006) (unpublished document, on file with author). 


\section{AFRICA'S DARING EXAMPLE}

The willingness of African states and institutions to codify a right to PDI and to openly condemn in the continent's foremost political body undemocratic seizures of power is a remarkable achievement and advancement in the jus ad bellum. Even more surprising is the willingness of African nations to contract away sovereignty and authority and to endow an organization with the political and legal clout to intervene in their internal affairs to safeguard democracy and human rights.

\section{FINAL WORDS}

The birth of this seemingly new African liberalism on the regional security and democracy fronts has resulted in a whittling away of the absolutist/positivist mantle of state sovereignty and nonintervention and an acceptance of the logic of sovereignty as responsibility. ${ }^{296}$ Africa's new paradigm of interventionism is not only taking seriously its responsibility to protect human rights and democracy ${ }^{297}$ but also helping to destroy the "tragic myth that the interests of the people are one with those of their national governments" (e.g., AU and ECOWAS action in Togo). ${ }^{298}$ Here, the nexus between democracy and responsible governance is unmistakable. While it is true that political elites often have mixed motives for supporting particular policy prescriptions, democrats and autocrats alike recognize that peace, security, and stability are precursors to accessing the foreign capital needed to create enabling environments for authentic political and economic development. Both reformers and thieves acknowledge that it is necessary to have some measure of stability to effectuate positive change in, or pilfer, the state; hence, there are incentives for both democrats and autocrats to operate in stable, conflict-free environments. This fact may explain the

\footnotetext{
296 See Francis M. Deng et al., Sovereignty as Responsibility: Conflict Management in AFRICA xvii (1996).

${ }^{297}$ See generally Jeremy I. Levitt, The Responsibility to Protect: A Beaver without a Dam?, 25 MICH. J. INT'L L. 153 (2003) (reviewing ICISS, The Responsibility to Protect, supra note 4; ICISS, The Responsibility to Protect: Bibliography, supra note 4).

${ }^{298}$ Ibrahim J. Gassama, Safeguarding the Democratic Entitlement: A Proposal for United Nations Involvement in National Politics, 30 CORNELL INT'L L.J. 287, 333 (1997).
} 
general consensus among political elites in Africa to bestow regional bodies with the authority to employ force to safeguard DCGs.

African states and their organizations have created the world's most advanced and legally coherent frameworks to combat conflict and regional insecurity and protect democracy. ${ }^{299}$ No other nations or regions have offered comparable structures nor demonstrated a similar willingness to sacrifice human and tangible resources and sovereignty for peace and democracy. While not every African intervention discussed above qualifies as PDI, the continuity in state practice and treaty-law developments confirms the existence of, and strengthens, the PDI norm.

The PDI norm has been spurred not only by state practice and treatylaw developments in Africa but by universal international law and practice and several interconnected occurrences, including the popular intervention by the UN and OAS in Haiti in 1994, recent decisions of the UN Credentials Committee not to accredit regimes that come to power by overthrowing democratic governments, and stern UN statements and declarations on the sanctity of democracy and the unlawfulness of unconstitutional seizures of power. For example, Secretary-General Annan stated that the "success of Africa's third wave depends equally on respect for fundamental human rights" and democratic rule. ${ }^{300}$ As previously noted, he has made the case that African states can no longer tolerate coups against elected governments or illegal seizures of power by military cliques and that the international community and African states must be dedicated to a new doctrine of African politics: "Where democracy has been usurped, let us do whatever is in our power to restore it to its rightful owners, the people." ${ }^{301}$ Elsewhere I have argued that "Annan's comments arguably marked the beginning of a pendulum shift away from the UN's practice of silence and inaction on issues it traditionally considered internal or within the exclusive jurisdiction of states-and to a new doctrine that

${ }^{299}$ However, the Organization of African States' adoption of the Inter-American Democratic Charter (2001) and Resolution 1080 (XXI-O/91) on representative democracy seem to indicate the organization's willingness to eventually build a viable conflict maintenance system.

${ }^{300}$ Press Release, The Secretary-General, Secretary-General Calls for Efforts to Unleash African 'Third Wave' Based on Democracy, Human Rights, and Sustainable Development, U.N. Doc. SG/SM/6245/Rev.1 AFR/9/Rev.1 (June 2, 1997).

${ }^{301}$ Id. Annan has also appealed to the international community to "ostracize and isolate putschists" and avoid mere passive verbal condemnations of coups against DCGs. He has even encouraged ECOWAS to "deal" with elected governments that "violate constitutional norms and flout basic principles of good governance." Press Release, The Secretary-General, Good Governmance [sic] Essential for Political Stability, Economic Growth Says Secretary-General in Message to West African Summit, U.N. Doc. SG/SM/9090 AFR/799 (Dec. 19, 2003) (delivered by Mr. Ahmedou Ould-Abdallah, Special Representative of the Sec'y-General and Chief of UN Office for West Africa). 
overrides state sovereignty to protect human rights and democracy." 302 Similarily, African states were the first to substantially force the pendulum to swing and hence are largely responsible for any normative shift.

Africa's new interventionism (backed by hard law), taken together with the international community's new attitude against unconstitutional seizures of power, has not only influenced state behavior inside and outside Africa; it has also added significant weight and shape to the development of the corpus of international law including the emerging norm of PDI and the doctrine of humanitarian intervention. Although it may be too early to claim that a right of PDI exists under customary international law, its recognition as a treaty-based right and one firmly established in customary regional law in Africa and arguably Latin America is both timely and futuristic.

302 Jeremy I. Levitt, Illegal Peace?: An Inquiry into the Legality of Power-Sharing with Warlords and Rebels in Africa, 27 MICH. J. INT'L. L. 495, 568 (2006). 
